\title{
O processo composicional intertextual de Estética do Frio III de Celso Loureiro Chaves
}

\author{
João Francisco de Souza Corrêa \\ Universidade Federal do Rio Grande do Sul | Brasil
}

\begin{abstract}
Resumo: Este artigo apresenta um estudo sobre os procedimentos composicionais intertextuais na obra Estética do Frio III: Homenagem a Leonard Bernstein (2014) de Celso Loureiro Chaves. Objetivou-se elucidar a sistemática do compositor em abstrair, organizar e reutilizar materiais musicais de obras próprias ou alheias ("textos") na criação da obra. O trabalho investigativo foi desenvolvido através da análise de manuscritos e partituras e de diálogos com o compositor. Observou-se que a utilização de elementos intertextuais forma uma sólida rede de conexões, dando coerência estrutural à composição.
\end{abstract}

Palavras-chave: Estética do Frio III, Celso Loureiro Chaves, Intertextualidade, Processo composicional, Análise musical.

\begin{abstract}
This is a study of intertextual procedures in Estética do Frio III: Homenagem a Leonard Bernstein (2014) (Aesthetics of the Cold III -Hommage to Leonard Bernstein) by Brazilian composer Celso Loureiro Chaves. Its intention is to demonstrate how intertextual compositional elements ("texts") were appropriated by the composer in the creation of his work. The investigation was conducted through analyses of manuscripts, study of scores, and interviews with the composer. It was observed that intertextual elements create a solid network of connections, imparting the composition with structural coherence.
\end{abstract}

Keywords: Aesthetics of the cold III, Celso Loureiro Chaves, Intertextuality, Compositional process, Musical Analysis.

The intertextual compositional process of Celso Loureiro Chaves's Aesthetics of the Cold III. Recebido em 14/04/2020. Aprovado em 24/05/2020. Disponível online: 30/09/2020. Editor: Dr. Felipe de Almeida Ribeiro. 


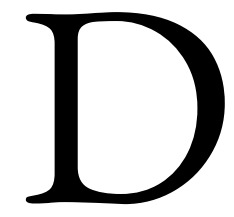
esde sua apresentação por Julia Kristeva (1967), o termo intertextualidade chama a atenção de muitos autores pertencentes a várias áreas de atuação. Em seu território de origem, o campo literário, a ideia de intertextualidade tem sido vista como um meio para interpretar o sentido de um texto, através de sua relação com outros textos. Essa busca por um significado, ancorada nas relações entre textos, levou a ideia de intertextualidade a receber muitas acepções por diferentes autores. Não ficando restrita às discussões empreendidas no campo literário, a ideia de intertextualidade logo se espalhou para outras áreas, como música, cinema, pintura, arquitetura, fotografia, e praticamente a todas as produções culturais e artísticas.

No campo musical, pesquisadores e compositores têm encontrado na intertextualidade uma ferramenta para investigar e empregar elementos externos em uma composição. Para a análise musical, em geral, a intertextualidade tem proporcionado uma perspectiva para mapear e compreender o modo como um compositor trabalha, em sua obra, elementos de outras obras. Para a composição, a intertextualidade, como pressuposto estético e ideológico, tem concedido múltiplas possibilidades inspiradoras e orientadoras da criação musical, como, por exemplo, a utilização de citações, alusões, ou procedimentos apropriados de outras composições, sem remissão explícita.

Diante deste cenário, este artigo apresenta um estudo baseado no processo composicional intertextual da peça Estética do Frio III: Homenagem a Leonard Bernstein (2014) de Celso Loureiro Chaves. Por processo composicional intertextual, entende-se o uso deliberado de materiais, motivos, temas, trechos ou ideais, apropriados de composiçôes, próprias ou alheias, para a criação de uma nova obra.

A discussão aqui empreendida está organizada em duas partes principais. $\mathrm{Na}$ primeira, Estética do Frio III é contextualizada através dos aspectos básicos que levaram à sua concepção e a nortearam. É descrito como o compositor pensa - no contexto da peça - a ideia de intertextualidade como processo composicional. A seguir, a peça é revisada sob o ponto de vista de sua estrutura. Aqui, além do detalhamento de como os eventos são organizados, ocorre também o mapeamento inicial sobre os textos utilizados pelo compositor ${ }^{1}$.

Na segunda parte, Estética do Frio III é revisada sob o ponto de vista dos textos e materiais

\footnotetext{
${ }^{1}$ Nesta análise, textos são entendidos como os materiais composicionais intertextuais (citações e diferentes tipos de elementos musicais abstraídos de outras obras, próprias ou alheias) utilizados pelo compositor na criação da peça.
} 
que o compositor insere na peça. Eles são inventariados com o intuito de demonstrar como ocorre o processo de sua apropriação e utilização por parte do compositor. Os elementos empregados pelo compositor são de dois tipos: textos citacionais e materiais do compositor.

Com auxílio de textos escritos pelo próprio compositor, manuscritos e depoimentos a este autor, o ato investigativo mostra como o compositor se apropria dos materiais referenciais, e como eu - enquanto ouvinte/pesquisador - percebo a criação da obra como exemplo de intertextualidade.

Ao final, explanam-se considerações sobre a peça e a análise realizada.

\section{Estética do Frio II: Homenagem a Leonard Bernstein (2014)}

Estética do Frio III: Homenagem a Leonard Bernstein de Celso Loureiro Chaves, para dois violinos, viola, violoncelo e piano, foi estreada pelo Quarteto Osesp com o pianista Jean-Efflam Bavouzet, em 4 de setembro de 2014. Esta obra adveio de uma encomenda da OSESP para uma 'homenagem a Leonard Bernstein', que foi o compositor transversal da temporada 2014. O título de Estética do Frio III, também expressa a continuação do trabalho desenvolvido em duas obras anteriores do compositor: Estética do Frio I (1993) e Estética do Frio II (2005). Nestas composições, componentes da obra Estética do Frio do escritor e compositor Vitor Ramil são integrados como elementos musicais generativos ${ }^{2}$.

De acordo com o compositor, o pensamento composicional de Estética do Frio III baseia-se no conceito de intertextualidade: “assim como nas outras 'Estéticas do Frio', a intertextualidade move a peça para diante” (CHAVES, 2014, p. 6). Embora Chaves (2018, p. 6) tenha definido a intertextualidade como "a incorporação de cacos das músicas dos outros”, seu entendimento do conceito é um pouco mais amplo. Ele está relacionado ao uso deliberado não só de elementos musicais (citações ou alusões abstraídas de outras composições próprias ou alheias), mas também a diferentes tipos de influência não musicais.

\footnotetext{
${ }^{2}$ Diferentemente de Estética do Frio Ie II, em Estética do Frio III não há referências musicais derivadas da conceituação estética formulada por Vitor Ramil, apenas uma epígrafe na partitura extraída de um trecho da letra da canção $A$ paixão de Vsegundo ele próprio.
} 
Seguindo este viés poiético intertextual ${ }^{3}$, Estética do Frio III contempla um feixe de materiais, abstraídos tanto de obras de outros compositores quanto de obras anteriores do próprio compositor. Além da abstração de um conjunto de citações de obras de Leonard Bernstein e do diálogo mantido com as duas Estéticas do Frio anteriores, Estética do Frio III faz referência a peças de Béla Bartók e Armando Albuquerque e a um poema de Elizabeth Bishop. "É sobre essa rede de intertextualidades que se desenha a Estética do Frio III” (Chaves, 2014, p. 6).

\subsection{Estrutura}

A estrutura de Estética do Frio III é constituída por três movimentos interligados. Cada um deles é organizado em diferentes seções, que variam de três a quatro, como revela a partiturá4. Estética do Frio III apresenta, no interior de algumas seções, segmentos contrastantes que tornam possível uma subdivisão ainda maior entre eventos. Um aspecto importante desta subdivisão em seções é que cada uma delas oferece uma característica sonora, uma paisagem aural particular, a qual, na maioria das vezes, contrasta significativamente com suas partes vizinhas.

O primeiro movimento, que se concentra nas cordas, inicia com uma autocitação de Estética do Frio I, acoplada a uma citação oculta ${ }^{5}$ de Cool de West Side Story de Leonard Bernstein. Este início resulta na seção sombre, na qual as cordas, em evidência, dialogam com o piano, que realiza pontuações e variações do acorde-âncora (um material harmônico, recorrente em outras obras do compositor). O primeiro movimento encerra-se com o 'liberamente', em que a atmosfera sonora apresenta um grau mais acentuado de tensão e intensidade. Os eventos finais deste movimento um sturm und drang ${ }^{6}$ com as notas de um motivo desenvolvido no segundo movimento e duas citações de Fancy Free de Bernstein - possuem dupla função. Estes eventos, além de encerrar o

\footnotetext{
${ }^{3}$ Segundo Klein (2005, p. 12), a intertextualidade poiética ocorre quando se atenta para os textos aos quais o autor recorreu para a criação de sua obra.

${ }^{4}$ Segundo informações dadas pelo compositor (2015), as letras da partitura de ensaio coincidem com as seções da peça. A estrutura referida na partitura indica: A - B - C - D - E - F - G - H - I - A'. O primeiro movimento é constituído por A (introdução) - B - C; o segundo por D - E - F; e o terceiro por G - H - I - A' (epílogo).

${ }^{5}$ As definiçôes das espécies de citaçóes (oculta, literal e fantasma) são apresentadas na seção que discorre exclusivamente sobre elas.

${ }^{6}$ No contexto deste estudo e da peça, sturm und drang refere-se à execução simultânea da mesma frase por todos os instrumentos, como em obras de Haydn e Beethoven.
} 
primeiro movimento, também configuram um pequeno parêntese, que estabelece uma conexão orgânica entre os movimentos.

O segundo movimento é constituído por três seções menores e contrastantes e caracteriza-se pela vinda do piano para o primeiro plano das ações. No início, con impeto, o piano desenvolve o padrão motívico do sturm und drang, enquanto as cordas apresentam uma citação literal de On The Town de Bernstein. O fluxo motórico ${ }^{7}$ desta seção é quebrado pelo pesante, local de confluência entre os materiais generativos que deram vazão à criação da composição. Em meio a estes materiais generativos, surge, no piano, a citação literal de Four Aniversaries $n^{\circ} 2$. Ao final deste movimento, uma lenta atmosfera sonora instala-se, na qual frases soltas ao piano dialogam com textos de Bartók e Albuquerque.

O terceiro movimento propõe uma lenta dissolução em direção ao fechamento da obra. O trecho deserto, constituído por um diálogo entre os violinos "é interrompido por uma miniatura para piano, Subways of Cement, inspirada em Elizabeth Bishop” (CHAVES, 2014, p. 6). Ao final desta cadenza do piano há, nas cordas, uma alusão à segunda sinfonia (The Age of Anxiety) de Bernstein. A seguir, vários textos citacionais, como On the Town, Maria e Chichester Psalms de Bernstein, são justapostos até colapsar em outros materiais do compositor (motto Celso e motivo Lucas $^{8}$ ). Estética do Frio III despede-se rememorando seu início, porém, desta vez, a execução em surdina apresenta uma atmosfera sonora onírica.

\section{Textos e materiais de Estética do Frio III}

Apresenta-se, nesta seção, um mapeamento das abordagens composicionais realizadas por Celso Loureiro Chaves, em Estética do Frio III. Aqui, o norte investigativo dirige-se para os textos e

\footnotetext{
7 'Fluxos', em meu entendimento, consiste na sonoridade que emerge do modo como os materiais e as ações instrumentais dispóem-se e comportam-se no continuum temporal de uma peça. Por fluxo motórico, entendo o resultado sonoro de açóes e materiais que proporcionam maior propulsão e movimento a uma obra. Neste tipo de fluxo, o movimento linear, constante e mais acelerado dos materiais sonoros, é preponderante em seu modo operacional.

${ }^{8}$ Este motivo corresponde a uma célula melódica formada pelas notas Lá, Dó, Dó, Lá e Mi bemol, que são as notas musicais referentes às iniciais do nome 'Lucas'. Esta relação ocorre através da conversão de letras em notas. O compositor revela que este monograma seria, originalmente, utilizado em uma composição para violão que não chegou a ser composta, e que sua origem advém do nome do intérprete ao qual a obra seria dedicada.
} 
materiais que o compositor aplica na criação da peça. Para melhor clareza conceitual, estes aspectos são organizados em dois grupos: 1) textos citacionais, que são os materiais musicais (citações e alusóes) apropriados de obras de outros compositores (Bernstein, Bartók e Albuquerque); 2) materiais do compositor, que abarcam tanto os textos próprios do compositor (autocitaçóes) quanto materiais musicais sem implicaçôes intertextuais composicionais (acorde-âncora e 12 acordes), no entanto fundamentais para a construção e entendimento da obra.

A ordem do conteúdo discutido a seguir assenta-se no tipo de procedimento composicional empreendido pelo compositor e não corresponde ao ordenamento dos acontecimentos musicais da peça. Para auxiliar a localização dos eventos aqui discutidos, a Tabela 1 mostra a posição de cada texto, recurso e material significativo da peça.

TABELA 1 - Mapa dos textos e materiais de Estética do Frio III

\begin{tabular}{|c|c|c|c|c|}
\hline Movimentos & Partes & Textos e materiais & Compassos & Instrumentos \\
\hline Introdução & $\mathrm{A}$ & $\begin{array}{c}\text { Estética do Frio I } \\
\text { West Side Story - Cool }\end{array}$ & $\begin{array}{l}\text { c. 1-9, Cordas } \\
\text { c. 1-6-, Piano }\end{array}$ & c. 7 , Piano \\
\hline & B & $\begin{array}{c}\text { Acorde-âncora } \\
12 \text { Acordes }\end{array}$ & c. 24-28-, Piano & \\
\hline I. & $\mathrm{C}$ & $\begin{array}{l}\text { Acorde-âncora } \\
12 \text { Acordes } \\
\text { Fancy Free }\end{array}$ & $\begin{array}{l}\text { c. } 52-54-\text { Piano } \\
\text { c. } 60-62 \text {, } \\
\text { Viola/violoncelo }\end{array}$ & $\begin{array}{l}\text { c. } 62-63 \text {, } \\
\text { Piano }\end{array}$ \\
\hline & $\mathrm{D}$ & $\begin{array}{c}12 \text { Acordes } \\
\text { On The Town - Lonely Town }\end{array}$ & c. $71-75$, Violinos & c. $83-84$, Viola \\
\hline II. & $\mathrm{E}$ & $\begin{array}{l}\text { Teoria dos acordes (12 acordes; Ritmo Vivat, } \\
\qquad \text { Vivat Regina! } \\
\text { Four Anniversaries: II - For Johnny Mehegan } \\
\text { Teoria dos Acordes }\end{array}$ & $\begin{array}{l}\text { c. } 97-102 \\
\text { c. } 104-107, \text { Piano } \\
\text { c. } 108-115\end{array}$ & \\
\hline
\end{tabular}


CORRÊA, João Francisco de Souza. 0 processo composicional intertextual de Estética do Frio III de Celso Loureiro Chaves. Revista

TABELA 1 (cont.) - Mapa dos textos e materiais de Estética do Frio III

\begin{tabular}{|c|c|c|c|c|}
\hline Movimentos & Partes & Textos e materiais & Compassos & Instrumentos \\
\hline \multirow{7}{*}{ II. } & \multirow{7}{*}{$\mathrm{F}$} & Quarto Quarteto deCordas & c. $118-122$ & \multirow{7}{*}{ Viola/Violoncelo } \\
\hline & & de Béla Bartók & & \\
\hline & & 12 Acordes & & \\
\hline & & Acorde-âncora & c. $122-127$, & \\
\hline & & Motivo Lucas & c. $123-127$ & \\
\hline & & Oração da Estrela Boieira de & \multirow[t]{2}{*}{ c. $126-127$} & \\
\hline & & Armando Albuquerque & & \\
\hline \multirow{15}{*}{ III. } & \multirow{3}{*}{ G } & 12 Acordes - Deserto & \multirow{3}{*}{$\begin{array}{l}\text { c. } 127-141 \\
\text { c. } 142-145\end{array}$} & \multirow{3}{*}{$\begin{array}{c}\text { Violinos/Violonce } \\
\text { lo }\end{array}$} \\
\hline & & Sinfonia $n^{\circ} 2$ - The Age of & & \\
\hline & & Anxiety & & \\
\hline & \multirow{4}{*}{$\mathrm{H}$} & Subways of Cement & \multirow{2}{*}{ c. $146-177$, Piano } & \\
\hline & & 12 Acordes & & \\
\hline & & Cadenza de The Age of & \multirow{2}{*}{ c. $166-177$, Viola } & \\
\hline & & & & \\
\hline & \multirow{8}{*}{ I } & Ecos de The Age of Anxiety & c. $179-180$, Viola & \\
\hline & & On The Town - Lonely Town & c. $178-182$, Piano & \\
\hline & & Ballet & & \\
\hline & & West Side Story - Maria & c. 185 & \\
\hline & & Chichester Psalms, III & c. $187-193$ & \\
\hline & & 12 Acordes & & \\
\hline & & Motivo Lucas & c. $192-195$ & \\
\hline & & Motto Celso & c. $196-200$ & \\
\hline Epílogo & $A^{\prime}$ & Estética do Frio I & c. $201-207$ & \\
\hline
\end{tabular}

Grafados em azul estão aos materiais do compositor (tanto os textos, quanto os recursos e materiais sem relação intertextual); em vermelho, os textos abstraídos da obra de Bernstein; em preto, as demais referências: Bartók, Albuquerque e Bishop. 


\subsection{Textos citacionais em Estética do Frio III}

O emprego de recursos composicionais intertextuais em Estética do Frio III ocorre ampla e variadamente. Além de elementos abstraídos de nove diferentes obras de Leonard Bernstein, Estética do Frio III apresenta referências de Bela Bartók, Armando Albuquerque e de obras anteriores do próprio compositor.

Em Roteiro da Paisagem', Chaves (2015) identifica alguns dos procedimentos envolvendo os textos citacionais, inclusive adotando nomenclatura própria para cada abordagem: citação, citação oculta, citação fantasma, fragmento, referência à memória. Em conversa pessoal, o compositor explicou que esta nomenclatura está associada ao modo como estes elementos são apropriados em Estética do Frio III. Estas diferenciações são em parte adotadas no presente estudo como um ponto de partida para a racionalização de como os textos são empregados na obra.

\subsubsection{Citações literais}

No artigo "Memória, citação e referência: os fluxos do tempo no 'Estudo Paulistano" de Celso Loureiro Chaves, o compositor define citação como a "busca e apropriação de material próprio ou alheio no âmbito [de uma] peça em processo de composição” (CHAVES, 2003, p. 3).

Para Burkholder (2001, s.p.),

A citação musical se distingue de outras formas de empréstimo pelo fato de que o material emprestado é apresentado exatamente ou quase exatamente como se encontrava no contexto original, diferentemente de uma alusão ou paráfrase, mas não constitui parte principal do obra em que se insere, como acontece em um cantus firmus, refrão, sujeito de uma fuga, tema com variaçóes e outras formas, e tampouco se apresenta completo como em um contrafactum, intabulatura, transcrição, medley ou potpourri. A citação desempenha um papel em outras formas de empréstimo musical como o quodlibet, a colagem e muitos exemplos de modelagem. A academia nem sempre tem observado estas distinções, e a citação e a sua contraparte alemã Zitat têm sido usados para se referir a uma grande variedade de práticas de empréstimo musical.

\footnotetext{
${ }^{9}$ Documento escrito pelo compositor, no qual descreve aspectos sobre a peça (2015).
} 
Para melhor clareza conceitual, aqui se denominam citações literais aquilo que Chaves (2015) descreve, em Roteiro da Paisagem, como citação, correspondente, basicamente, ao que Burkholder designa como citação musical. As citações oriundas do repertório autoral do compositor aqui se denominam como autocitações. Portanto, citação literal é entendida, neste estudo, como um fragmento musical que foi recortado da obra original, sem alterações, e recolocado na obra.

As citações literais de obras de Leonard Bernstein em Estética do Frio III são: 1) dois excertos do balé Fancy Free (1944); 2) um padrão escalar da segunda miniatura para piano de Four Anniversaries II - For Johnny Mehegan (1948); 3) uma frase com notas repetidas no piano do movimento The Dirge da Sinfonia no 2 - The Age of Anxiety (1949); 4) a melodia da introdução de Lonely Town Ballet do musical On the Town (1944); 5) um trecho da melodia da canção Maria de West Side Story (1957); 6) o início do coral do terceiro movimento de Chichester Psalms (1965).

Em Estética do Frio III, as citaçôes literais são expostas de modo isolado, sem elementos justapostos a elas, havendo, na maioria das vezes, somente o conteúdo citacional. Suas aparições são inesperadas e ocupam um curto espaço de tempo.

Nas citações literais, o contorno melódico e o ritmo são preservados. A instrumentação, a tonalidade e o registro podem sofrer algum tipo de adaptação, como nas citaçóes abstraídas de Maria, Chichester Psalms e uma de Fancy Free, em que algum deles é alterado ${ }^{10}$.

FIGURA 1 - Lonely Town, Pas de deux e Estética do Frio III ${ }^{11}$.

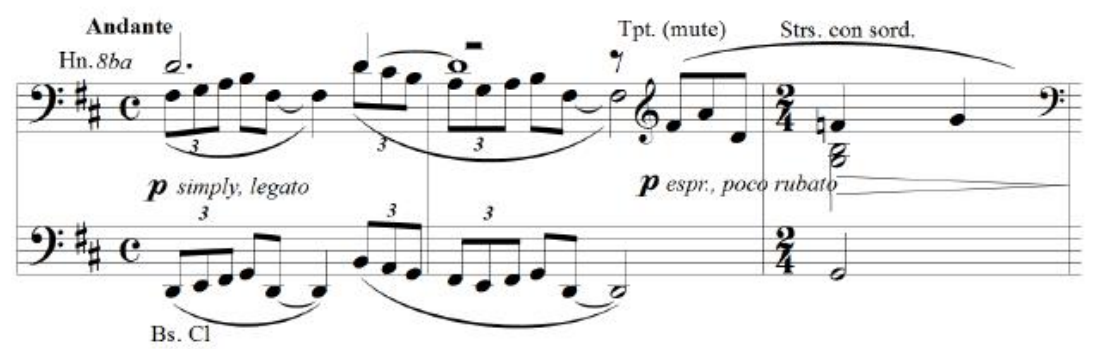

\footnotetext{
${ }^{10}$ Considero mais maleáveis os elementos de instrumentação, tonalidade e registro, pois uma transposição (desde que não seja de forma drástica) de timbre, tom ou registro não afeta (ou ao menos não impede) a identificação do material como sendo uma citação.

${ }^{11}$ Todos os exemplos musicais deste artigo são baseados no sistema francês, em que o Dó central é o Dó 3.
} 


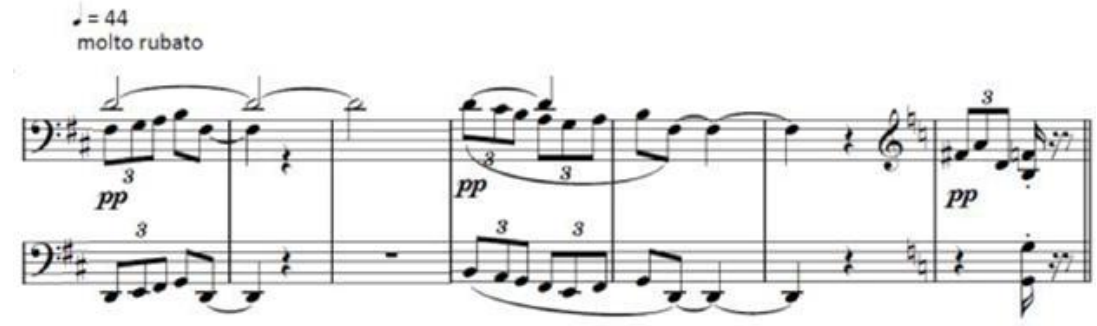

$\mathrm{Na}$ Fig. 1, a imagem à esquerda apresenta o excerto da redução para piano de Lonely Town, Pas de deux c. 1-3, a da direita expóe como o mesmo trecho é revivido em Estética do Frio III c. 178185. Afora o andamento e o leve aumento de espaço (ressonância das notas) entre as frases, o conteúdo citacional é transportado literalmente de uma obra para outra.

Em uma passagem no final da parte G (deserto) c. 142-145, há uma citação literal da seção do meio do movimento The Dirge da Sinfonia $n^{\circ} 2$, The Age of Anxiety.

FIGURA 2 - Estética do Frio III c. 141-145; segunda parte de The Dirge c. 7-10 de “4”.
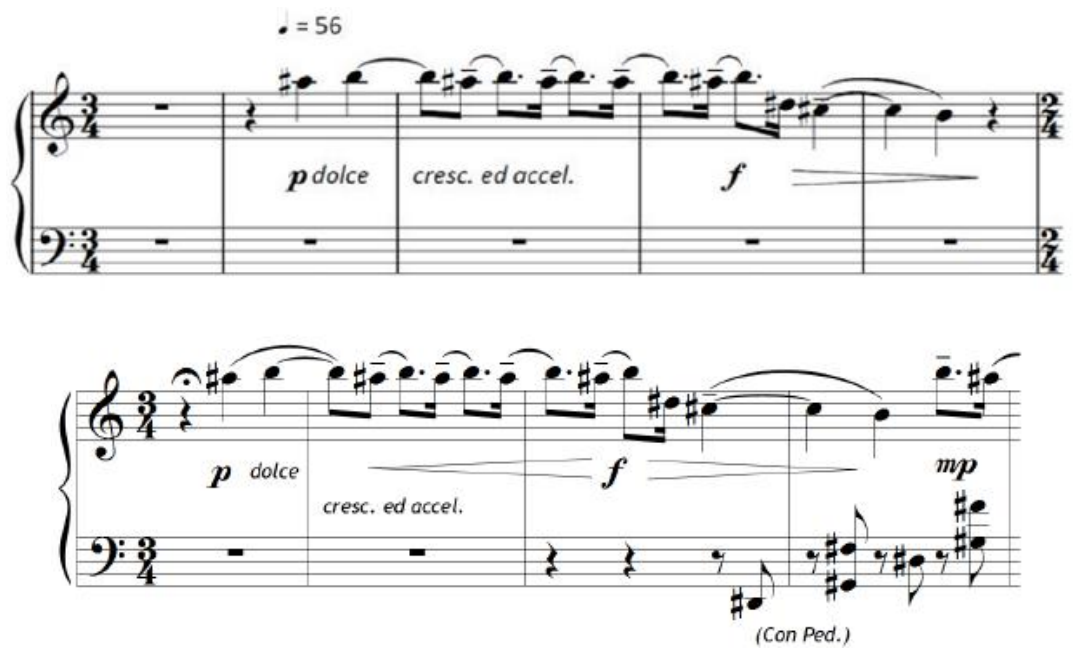

$\mathrm{Na}$ citação literal de The Age of Anxiety, a ação instrumental é mantida intacta, sem qualquer tipo variação ou adaptação. Aspectos como ritmo, melodia, instrumentação, intensidade, expressividade e agógica são todos mantidos, tornando fácil a identificação deste segmento como um material referencial. 
A diferença principal deste motivo em cada peça fica a cargo do contexto e da funcionalidade. Enquanto ele é amplamente desenvolvido em The Dirge, em Estética do Frio III aparece como uma rememoração isolada e passageira. Se em The Dirge é o material estruturante que dá vazão a um trecho inteiro, em Estética do Frio III ele consome a si mesmo, atuando principalmente como um elemento conectivo entre seções distintas.

Em Fancy Free, o conteúdo melódico do duo de flautas é transportado para a viola e o violoncelo, bem como a tonalidade. Em outra citação literal, um fragmento de Maria de West Side Story é adaptado da voz para a viola, tornando ausente a letra da canção.

Este tipo de adaptação instrumental ocorre novamente quando o coral do terceiro movimento de Chichester Psalms, construído a partir do Salmo 133, é instrumentado para as cordas de Estética do Frio III. Segundo Nash (2009, p.19), o sentido deste trecho, em Chichester Psalms, diz respeito “à coexistência pacífica de todas as pessoas e culturas e a aceitação de todas as crenças”. Em Estética do Frio III, a citação de Chichester Pslams é interrompida de modo intermitente por ações contrastantes no piano (rumblings). Devido à configuração rítmica e intervalar das ações do piano, contrastantes em relação ao material abstraído de Chichester Psalms, a atmosfera sonora deste trecho, em Estética do Frio III, adquire um caráter singular. Embora o material abstraído possa ser facilmente identificado (mesmo com a adaptação instrumental e a ausência do texto), devido às ações intermitentes do piano, o caráter sonoro e a intencionalidade em relação à obra precedente transformam-se. Assim, ao mesmo tempo que a citação é identificável, a mudança de contexto proporciona-lhe uma nova roupagem. Isso advém preponderantemente porque as alteraçóes estruturais não ocorrem no material abstraído e sim em seu entorno. 
FIGURA 3 - Trecho do terceiro movimento de Chichester Psalms c. 60-61 e sua exposição em Estética do Frio III c. 187-190.
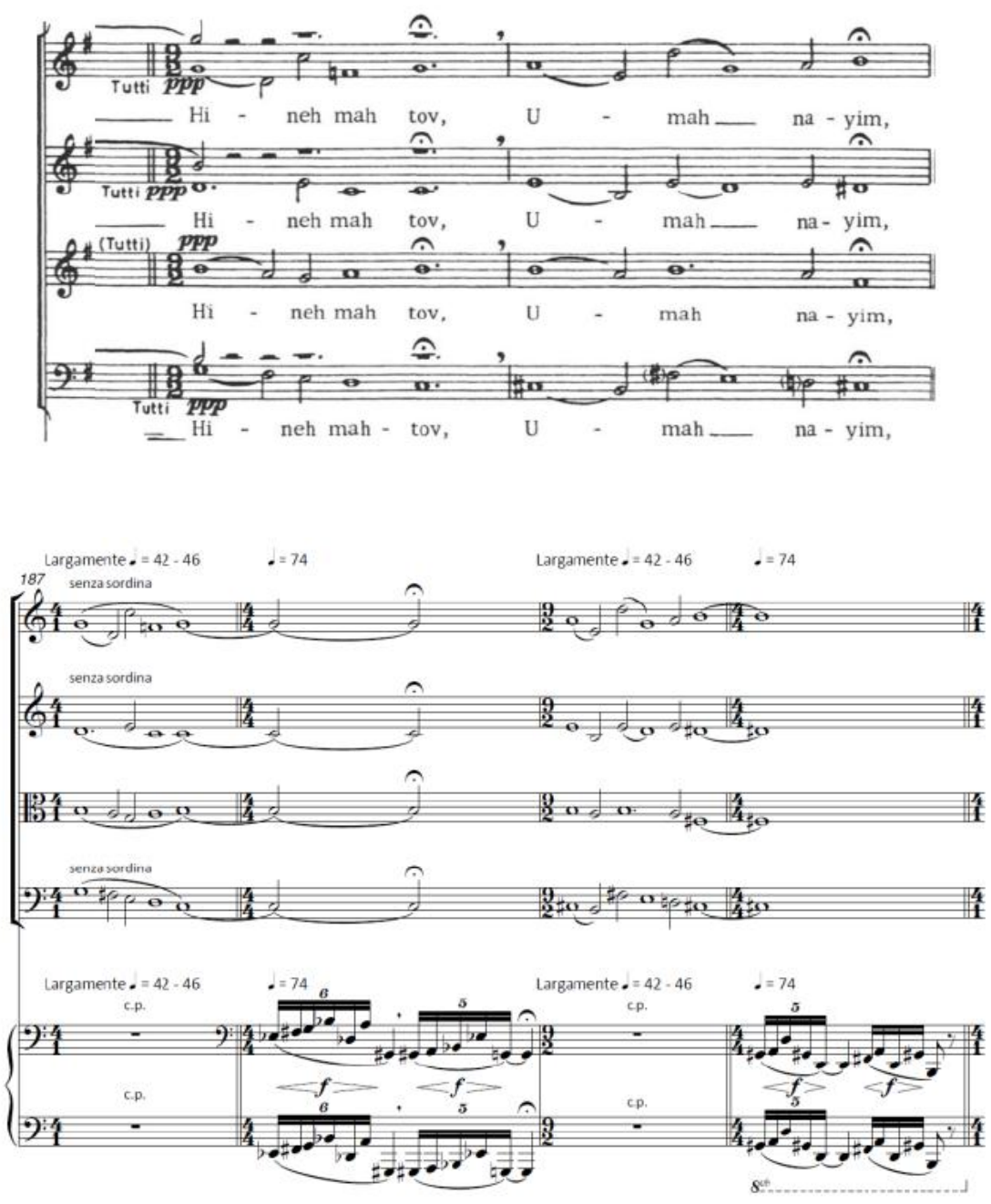

\subsubsection{Citação oculta}

Logo no início de Estética do Frio III - entremeado com a autocitação de Estética do Frio Iaparece um pequeno fragmento da melodia da voz de Cool de West Side Story ${ }^{12}$. A este fragmento, Chaves denomina citação oculta. Neste caso, o contorno melódico da citação é preservado, mas o ritmo, o andamento, a tonalidade, o registro, o contexto instrumental são modificados e adaptados a novas condiçốes. Com estas transformações, a citação é descaracterizada - o que se ouve não se reconhece.

\footnotetext{
${ }^{12} \mathrm{O}$ caráter melódico deste trecho baseia-se, fundamentalmente, no intervalo de trítono, que representa o "ódio ou o interminável conflito” entre as duas gangues (ROSS, 2007, p. 430).
} 
Se, em Bernstein, este fragmento corresponde à linha da voz, inserida em um contexto contrapontístico complexo, ao estilo fuga bebop, em Chaves, ele é estruturalmente recriado no piano e alocado ao contexto sonoro da autocitação de Estética do Frio I. Com estas mudanças, a citação oculta de Cool torna-se diluída em meio à textura ${ }^{13}$.

FIGURA 4 - Cool - West Side Story. À esquerda, a frase da melodia da voz de Cool c. 34 - 35, abstraída da redução para piano e vozes. À direita, a ação instrumental do piano no início de Estética do Frio III c. 1.

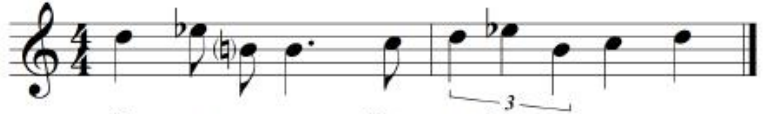

Go, man, go, But not like a yo - yo

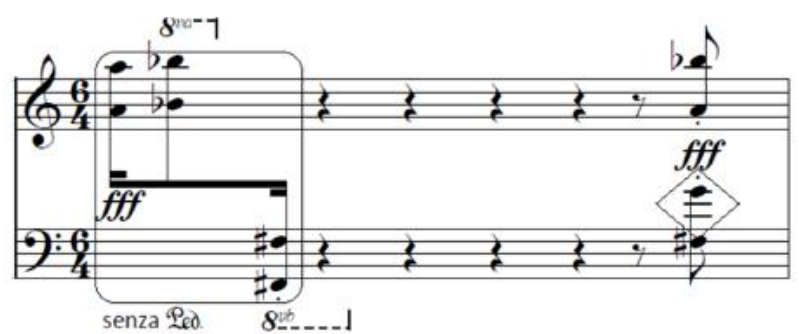

\subsubsection{Citação Fantasma}

Segundo a descrição contida em Roteiro da Paisagem, sempre que há, na partitura, indicações de sul ponticello, estão presentes as 'citações fantasmas' de On the town, Lonely Town $(1944)^{14}$.

Assim como as citaçôes literais, as citações fantasmas conservam a melodia e o ritmo originais, entretanto, segundo o compositor $(2016)^{15}$, elas se diferenciam porque as fantasmas ficam entremeadas com outros materiais. Embora o compositor assim defina citação fantasma, alguns eventos de "Estética do Frio III" mostram que a sobreposição de materiais distintos, envolvendo elementos referenciais, não é um aspecto exclusivo dela. É possível, portanto, estender a definição de citação fantasma para aquelas citações que se encontram entremeadas com outros materiais de tal modo que seu conteúdo referencial se torna obscurecido em meio à textura.

Em Estética do Frio III, a disposição simultânea entre diferentes materiais/açóes instrumentais cria uma densa camada textural e, em consequência, o conteúdo citacional de $O n$ the

\footnotetext{
${ }^{13}$ Sob essas circunstâncias, a referência a Cool esvazia-se de tal maneira que sua percepção como um momento alusivo na peça torna-se muito difícil. A alusão fica evidente apenas pela autocitação de Estética do Frio I.

14 São três os fragmentos abstraídos para Estética do Frio III. Eles aparecem na forma de pequenas intervenções melódicas situadas em c. 71 - 75, como duo de violinos; c. 83 - 84, na viola; c. 87-88, no primeiro violino.

${ }^{15}$ Conversa pessoal. Explicações sobre o processo composicional de Estética do Frio III, durante as orientações do doutorado. Notas de aula. Material não publicado. 2016.
} 
town, Lonely Town fica obscurecido. A citação aparece em plano discursivo inferior, estando em evidência outras açốes, principalmente as do piano (que conduz o discurso da parte D). Nesta interpolação de ações, a citação, embora pouco descaracterizada, perde sua carga referencial.

FIGURA 5 - Estética do Frio III c. 71 - 75.

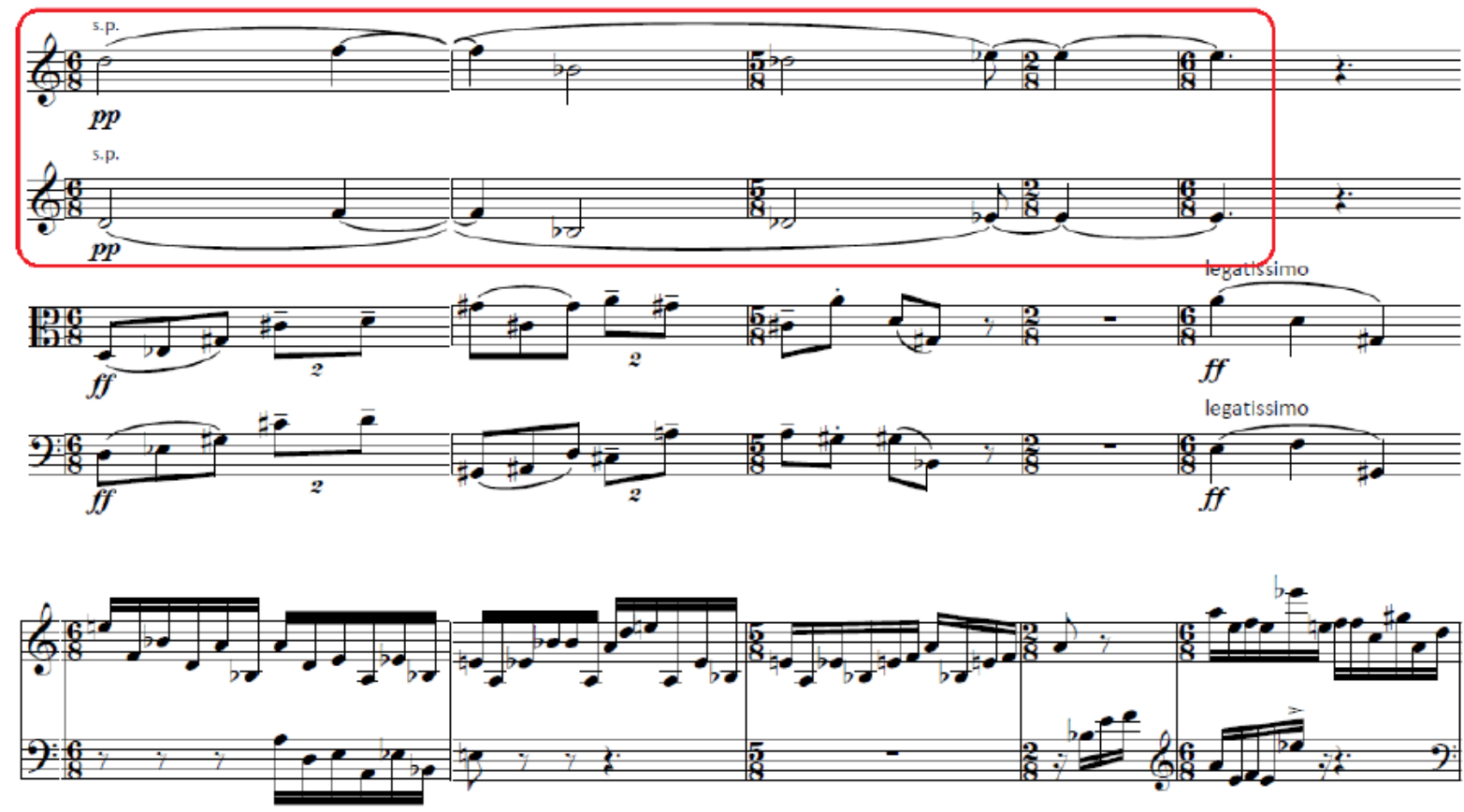

O excerto sublinhado, na Fig. 5, mostra uma das citações fantasmas de On the town, Lonely Town em Estética do Frio III. No mesmo trecho estão presentes duas outras camadas texturais, uma executada pelas açóes aceleradas no piano (plano principal), outra constituída por frases envolvendo a viola e o violoncelo. Por efeito destas três camadas instrumentais distintas, a citação de On the town, Lonely Town dilui-se em meio à textura.

Straus (1990, p. 17) denomina marginalização o procedimento em que o compositor abstrai um tema ou melodia principal de uma composição alheia e o utiliza, em sua obra, como recurso decorativo. Assim, elementos centrais da obra precedente são relegados, na nova, a um plano periférico. Em On The Town, Lonely Town este fragmento consiste na linha principal, em Estética do Frio III a mesma melodia é destituída de seu papel de evidência, em um processo semelhante à ideia de marginalização, diferente do que acontece com algumas citações literais, nas quais a citação, mesmo dividindo espaço com outros materiais, é colocada em evidência em meio à textura. 


\subsubsection{Referência à memória}

Entre os c. 118-122 de Estética do Frio III, ocorre o que o compositor chama de "referência à memória” do Quarto Quarteto de Cordas (1928) de Béla Bartók. Neste caso, não existe o emprego de um trecho específico da obra e sim uma impressão ligada à sua totalidade, inspirada especificamente nos efeitos de orquestração e timbragem dos instrumentos que decorrem da visualidade da partitura da peça.

FIGURA 6 - Estética do Frio III c. 116-122. O trecho sublinhado representa o evento de Estética do Frio III c. 118-122 criado a partir do Quarto Quarteto de Cordas de Béla Bartók.

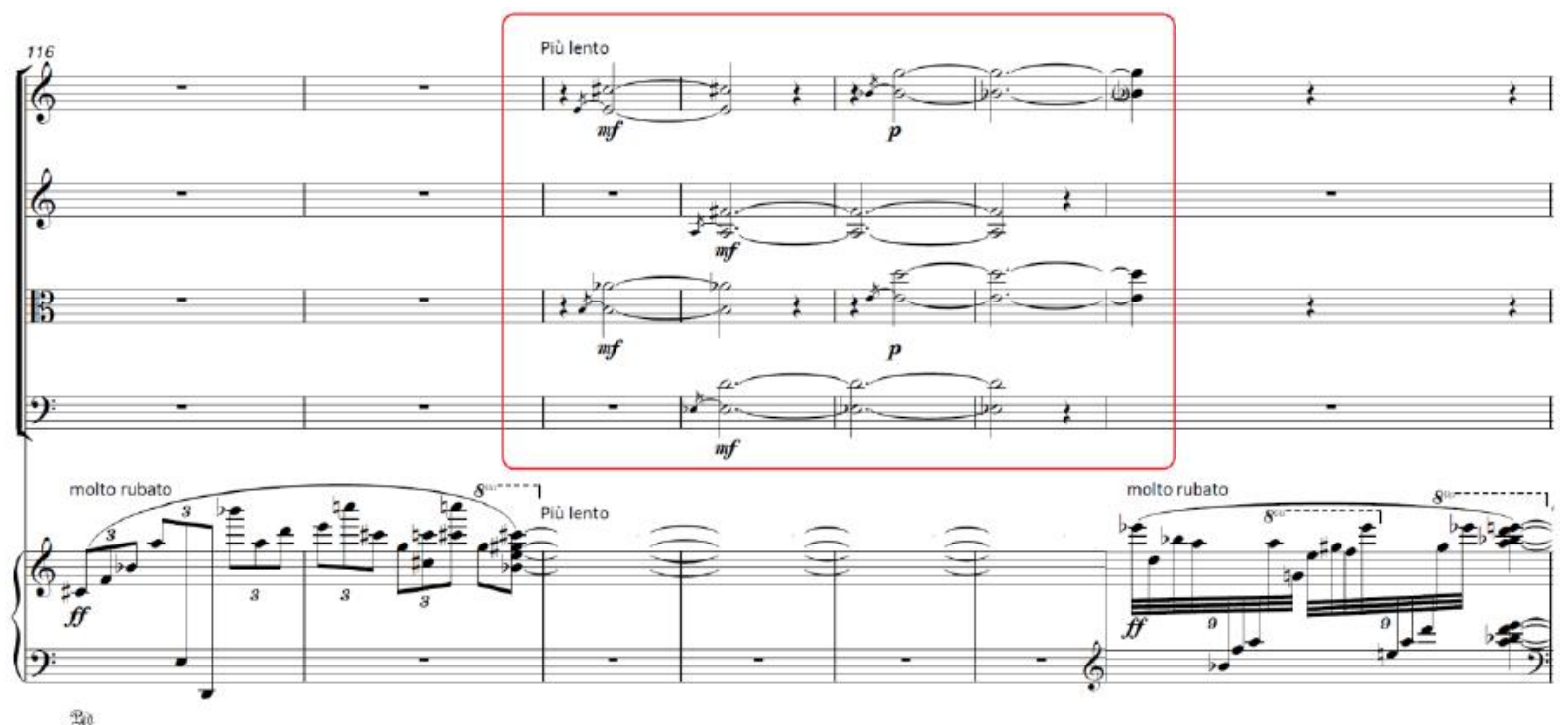

Esta ação instrumental envolvendo a referência a Bartók é constituída por, basicamente, três blocos harmônicos de quatro notas cada, distribuídos em duas camadas instrumentais (o primeiro e o terceiro acorde são executados pelo primeiro violino e pela viola e o segundo acorde, pelo segundo violino e pelo violoncelo). Este trecho ocorre na seção F c. 116-127, a última das três do segundo movimento.

Torna-se pertinente, neste ponto, expor parte de Chaves $(2003)^{16}$. Ali, o compositor analisa, em retrospecto, o processo composicional do Estudo Paulistano, estabelecendo um paralelo com as

\footnotetext{
${ }^{16}$ CHAVES, Celso. Memória, citação e referência: os fluxos do tempo no "Estudo Paulistano" de Celso Loureiro Chaves (2003).
} 
proposições contidas no escrito Fragmentos sobre a fenomenologia da música de Alfred Schutz. De acordo com Schutz "a experiência musical está baseada na faculdade mental de recuperar o passado através de retenções e reproduções e de pressupor o futuro através de protenções e antecipações” (SCHUTZ, 1976, p. 46). Através dos processos de 'retenção'17 e 'reprodução' ${ }^{18}$ propostos por ele, caracterizados como dois tipos de rememorações daquilo que se denomina lembranças, Chaves encontra pontos de contato com a metodologia de Schutz para desvelar a experiência criativa realizada no Estudo Paulistano.

O conceito de memória como entendido no processo composicional do Estudo Paulistano consiste no que Schutz (1974, p. 29) chama de memória retrospectiva, o território das "rememorações dentro da lembrança". Esta ideia explica a experiência envolvendo o Quarto Quarteto de Cordas de Bartók, pois, impulsionado por uma imagem resgatada das lembranças do compositor, o evento musical dos c. 118-122 é deflagrado.

\subsubsection{The Age of Anxiety}

No fim da cadência do piano c. 166 - 177 do trecho Subways of Cement, ocorre outra experiência distinta em relação às abordagens composicionais intertextuais. Neste ponto, o Roteiro da Paisagem refere-se à "participação da viola como se fosse o segundo piano da cadenza de The Age of Anxiety" (CHAVES, 2014, p. 3).

Em The Age of Anxiety, esta cadenza - que foi adicionada por Bernstein, em 1965, em uma revisão realizada dezesseis anos após a estreia - situa-se no epílogo da segunda parte. De acordo com Gentry (2011) tal adição proporcionou novo nível de tensão dramática à peça. Este trecho soa como se o "pianista tentasse improvisar resoluções para as tensões temáticas da obra” (GENTRY, 2011, p. 326-327). Segundo o texto presente na partitura, neste ponto da peça

\footnotetext{
${ }^{17}$ O processo de retenção ocorre quando há atitudes refletivas por parte do ouvinte "em relação a alguma experiência que foi verdadeira num Agora recém passado". Portanto, a lembrança cola-se imediatamente à experiência presente e, embora mergulhe no passado, a experiência verdadeira ainda é retida (SCHUTZ, 1976, p. 40-41).

${ }^{18}$ Este segundo tipo de lembrança "não se cola imediatamente às experiências presentes. Ela se refere a Passados mais remotos que são reproduzidos nessas rememoraçôes de outras experiências que tenham emergido entre o Agora passado, no qual o objeto rememorado de nosso pensamento foi verdadeiramente experienciado, e o Agora presente, no qual [o objeto] está sendo rememorado" (SCHUTZ, 1976, p. 40-41).
} 
o piano-protagonista é traumatizado pela intervenção da orquestra em jazz agitado. Quando a orquestra para, tão abruptamente quanto começou, um pianino na orquestra continua a Masque, repetidamente e com energia minguante, quando começa o Epílogo. Assim, uma espécie de separação do eu da culpa da vida escapista foi efetuada, e o protagonista está livre novamente para examinar o que é deixado sob o vazio (Nota do prefácio da partitura de The Age of Anxiety, edição Boosey \& Hawkes, 1993) ${ }^{19}$.

A memória do efeito das reminiscências executadas pelo pianino é o elemento abstraído por Chaves neste segmento de Estética do Frio III. Diferentemente da maioria das abordagens composicionais intertextuais, em que o compositor consultou a partitura das obras citadas, aqui Chaves contou com o auxílio de sua memória auditiva e de impressóes da obra.

FIGURA 7 - The Age of Anxiety e Estética do Frio III. Os dois pentagramas do topo da imagem referem-se ao trecho da cadenza de The Age of Anxiety ${ }^{20}$, os dois abaixo mostram o trecho de Estética do Frio III c. 166-180.

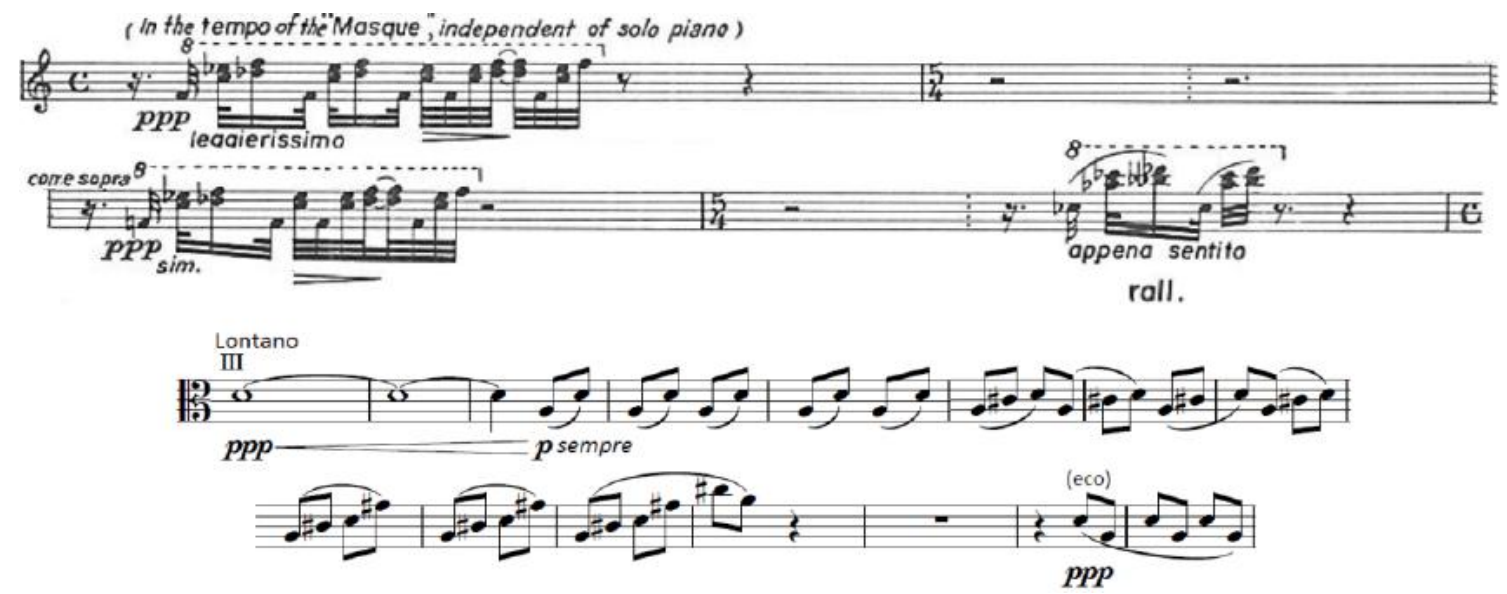

Em ambos os eventos deflagrados a partir da memória (Bartók e Bernstein), ocorre intertextualidade no nível poiético. Diferentemente do processo composicional envolvendo citaçôes (literal, oculta e fantasma), o elemento referencial não são os materiais e sim o mote, que faz emergir novo evento musical. Ou seja, neste tipo de abordagem composicional, a referência não é buscada na partitura, como nas citaçóes, mas em lembranças auditivas e visuais do compositor. Consequentemente, o resultado sonoro destas abordagens distancia-se das obras de origem.

\footnotetext{
${ }^{19}[\mathrm{~T}]$ he piano-protagonist is traumatized by the intervention of the orchestra for four bars of hectic jazz. When the orchestra stops, as abruptly as it began, a pianino in the orchestra is continuing the Masque, repetitiously and with waning energy, as the Epilogue begins. Thus a kind of separation of the self from the guilt of escapist living has been effected, and the protagonist is free again to examine what is leftbeneath the emptiness (Nota do prefácio da partitura de The Age of Anxiety, edição Boosey \& Hawkes, 1993).

${ }^{20}$ Este trecho situa-se nove compassos antes do J de The Epilogue.
} 


\subsubsection{Fragmento}

"Fragmento" é como o compositor descreve, em Roteiro da Paisagem, a alusão à canção Oração da Estrela Boieira (1943) de Armando Albuquerque. Aqui, o material recolhido pelo compositor são as notas da frase inicial da canção, abstraídas sem transposições. Entretanto, alguns componentes são modificados e descaracterizam o fragmento melódico original, o transformando. A própria mudança no contexto instrumental, passando do canto para a viola, torna ausentes os versos de Augusto Meyer do material original. No entanto, a mudança de contexto que considero mais significativa é a alteração rítmica (ver Fig. 8).

FIGURA 8 - Oração da Estrela Boieira e Estética do Frio III. O pentagrama superior representa o fragmento de Oração da Estrela Boieira c. 2-5, o inferior, os compassos c. 126 - 127 de Estética do Frio III.

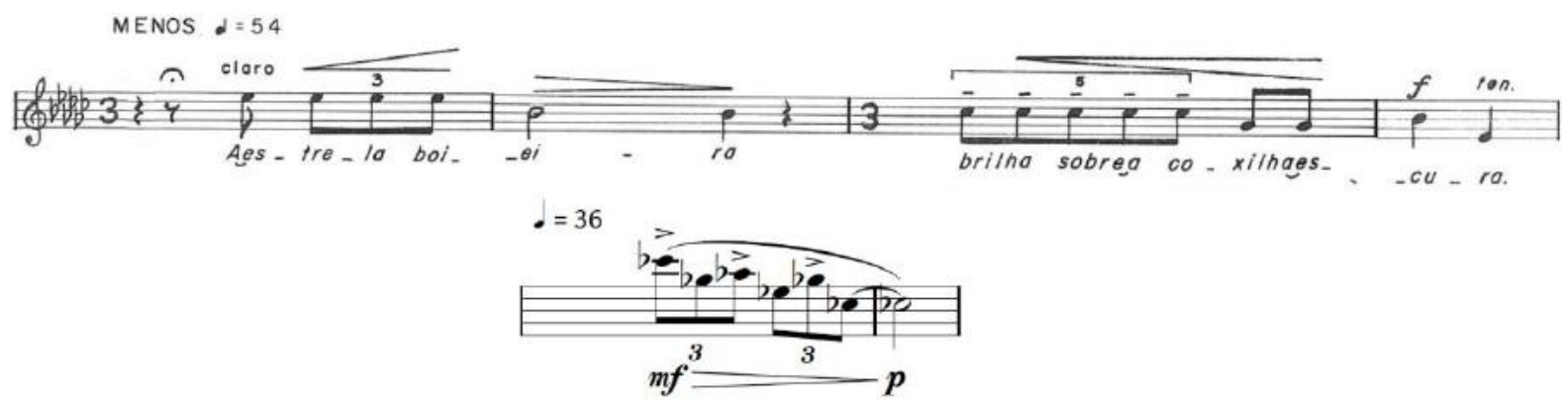

Diferentemente das duas anteriores experiências composicionais intertextuais, neste caso, o compositor parte de um elemento musical objetivo, uma frase. Entretanto, apesar disto, ele não reproduz nem adapta o material original, como faz quando abstrai citações, mas transforma o material referencial em novo evento musical. Da frase da canção, Chaves abstrai o conteúdo intervalar para compor a nova melodia, mas a alteração dos demais parâmetros (principalmente no ritmo) faz com que o ato criativo resulte em algo estruturalmente distante da frase original. A compressão rítmica descaracteriza de tal forma o material referencial original que sua apreensão como um elemento alusivo torna-se muito difícil. 


\section{2. Materiais do compositor: autocitações, acorde-âncora e doze acordes}

A presente seção discorre sobre os materiais próprios que o compositor utiliza em Estética do Frio III. Estes materiais são aqui identificados de três formas:

1) autocitações - consistem em textos que derivam da reutilização deliberada de materiais de obras anteriores. As autocitaçóes presentes em Estética do Frio III são um fragmento de Estética do Frio I e o motto Celso.

2) acorde-âncora - correspondem a um conjunto de alturas que, apesar de não estar associado a uma intertextualidade no âmbito composicional, apresenta implicações intertextuais no nível estésico $^{21}$. Estas implicações decorrem da presença, em outras obras do compositor, do mesmo conteúdo harmônico (sob diferentes formas estruturantes) do acorde-âncora.

3) doze acordes - consistem em um conjunto de acordes utilizados por Chaves para criar parte do conteúdo melódico e harmônico da peça. Embora não se trate de um material com implicações composicionais intertextuais, os doze acordes representam, no contexto processual, o epicentro da maioria das tomadas de decisão. Nesse sentido, torna-se imperativo, nesta análise, uma reflexão sobre seu funcionamento, já que muitas das conclusôes sobre o processo composicional intertextual, descritas mais adiante, levam em consideração sua presença e importância ${ }^{22}$.

\subsubsection{Autocitações}

Nas autocitações, um evento ou fragmento é recortado e transportado de uma obra para outra, semelhante ao processo realizado com algumas citaçóes literais de Bernstein.

Chaves relata que, quando recebeu a encomenda de Estética do Frio III, decidiu que utilizaria um fragmento de Estética do Frio I para iniciar e terminar a obra, sendo esta a primeira tomada de

\footnotetext{
${ }^{21}$ Segundo Klein (2005), a intertextualidade estésica ocorre quando se atenta para os textos que o leitor/investigador traz para a sua leitura/escuta.

${ }^{22}$ A utilização de um conjunto de acordes como fonte de melodias e harmonias para a criação de uma obra é uma abordagem composicional recorrente do autor. Procedimentos semelhantes a este também ocorrem em Estética do Frio II (2005), Um ponto ao Sul/Scattered Loves (2011), Museu das coisas inúteis (2017).
} 
decisão do processo criativo. Estética do Frio I foi construída a partir da ideia de fragmentos e este trecho consiste apenas em uma parte de seu conteúdo. Em Estética do Frio III este fragmento - de grande impacto expressivo devido à densidade e ao movimento - soma-se ao piano. Este evento de Estética do Frio I é responsável por abrir e encerrar Estética do Frio III.

FIGURA 9 - Estética do Frio I e Estética do Frio III. A imagem à esquerda é c. 22-23 de Estética do Frio I; a imagem à direita corresponde à mesma ação instrumental nos primeiros compassos de Estética do Frio III (parte A, Introdução). A mesma ação instrumental também está nas cordas em c. 3, 5, 7, 9, 201, 203, 205 e 207. Na seção A‘ (Epílogo), ocorre uma "reprise reduzida da Introdução (...) retomando a ideia retórica inicial da origem de toda a composição, quando a ideia ainda era compor uma peça para violão solo [frase que está no manuscrito]” (CHAVES, Roteiro da Paisagem, 2015, p. 3).
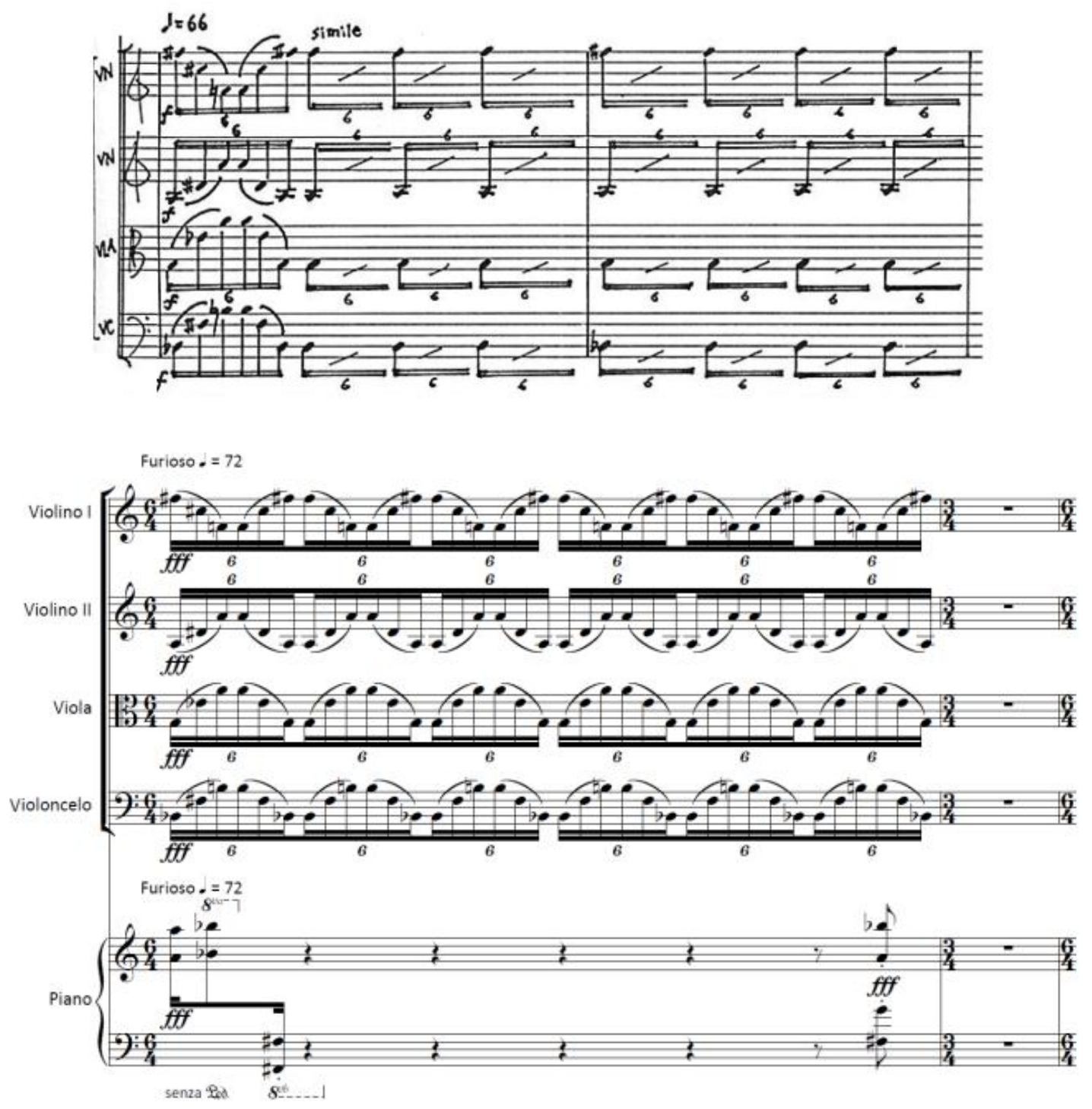
Nos compassos finais da seção I de Estética do Frio III, surge, em meio a vários outros materiais, o motto Celso. Segundo o compositor, o motto Celso consiste em sua assinatura musical, presente em todas as suas composiçôes "para que a tradição não se [quebre]” (2003, p. 4). Estruturalmente, o motto Celso são dois pequenos motivos (o primeiro formado pelas notas $\mathrm{Mi}$, Fá\# e Sib, o segundo, por Dó\#, Ré e Sib) que formam dois agregados harmônicos de três notas cada.

O motto Celso é um material dotado de grande potencial intertextual, pois perpassa boa parte do catálogo do compositor. Entre seus textos, o motto Celso figura como o elemento intertextual mais significativo, devido à sua ampla recorrência. Além de costurar todo o repertório autoral, este material estabelece uma marca pessoal em cada uma de suas composiçóes.

FIGURA 10 - Motto Celso em Estética do Frio III c. 196-199 e Estudo Paulistano - sexto pentagrama (segundo pentagrama da página 2).

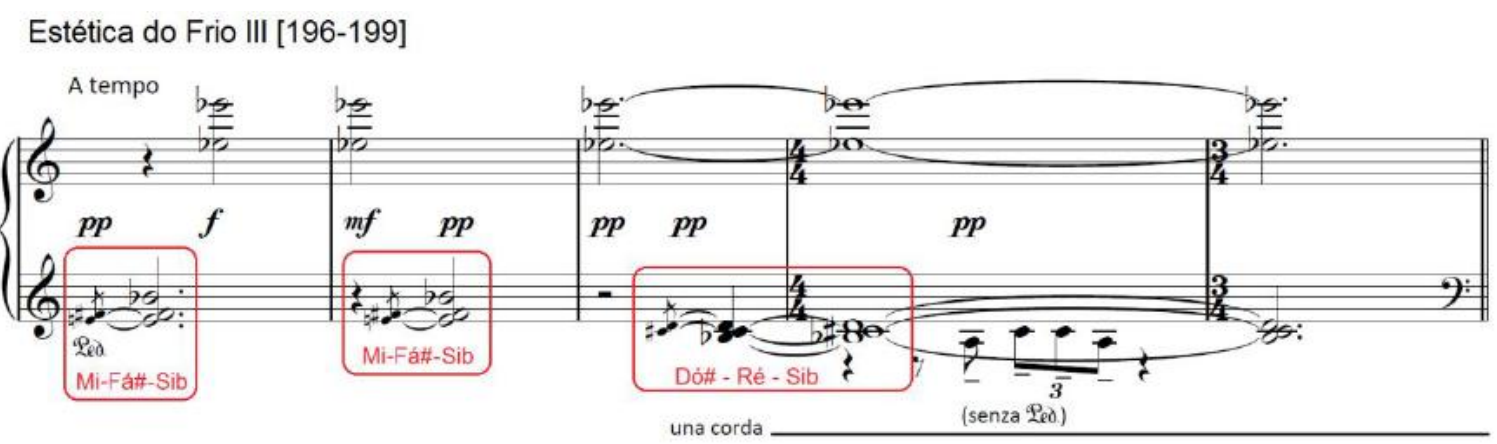

Estudo Paulistano $\left[6^{\circ}\right.$ pentagrama $]$

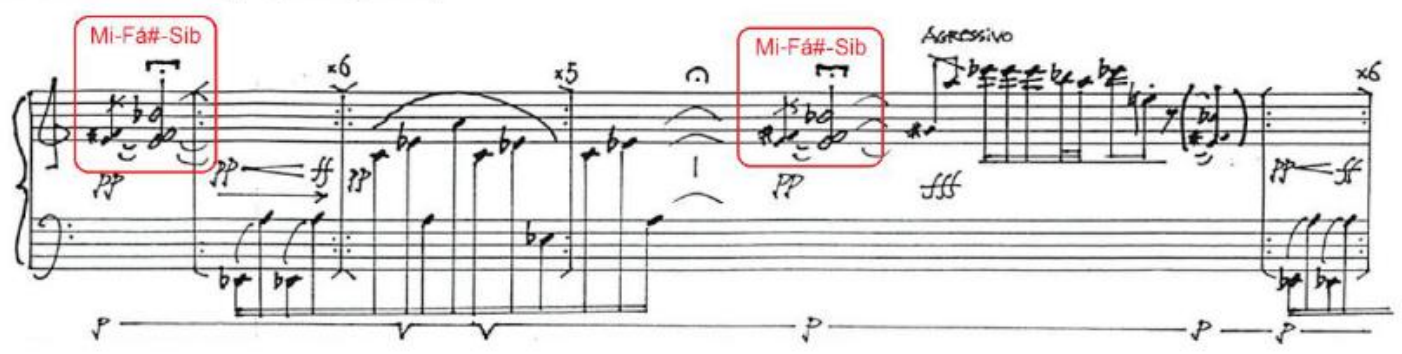


FIGURA 11 - motto Celso. A imagem mostra o motto Celso em quatro obras distintas de Celso Loureiro Chaves: no alto, à esquerda, na primeira peça do compositor - Sobre um Poema de Mário de Andrade para piano - composta em 1973; abaixo, à esquerda, em Balada para um avião que deixa um rastro de fumaça no céu (1980); no alto, à direita, em

Estética do Frio II (2005); abaixo, à direita, em Engenharia de Papel (Paper Engineering) para piano (2007).

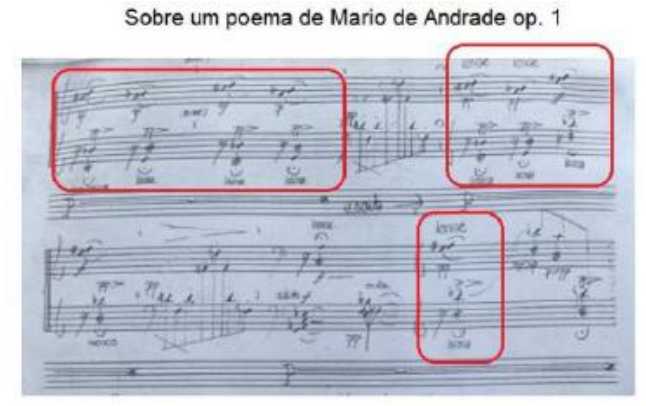

Balada para um avião que deixa um rastro de fumaça no céu

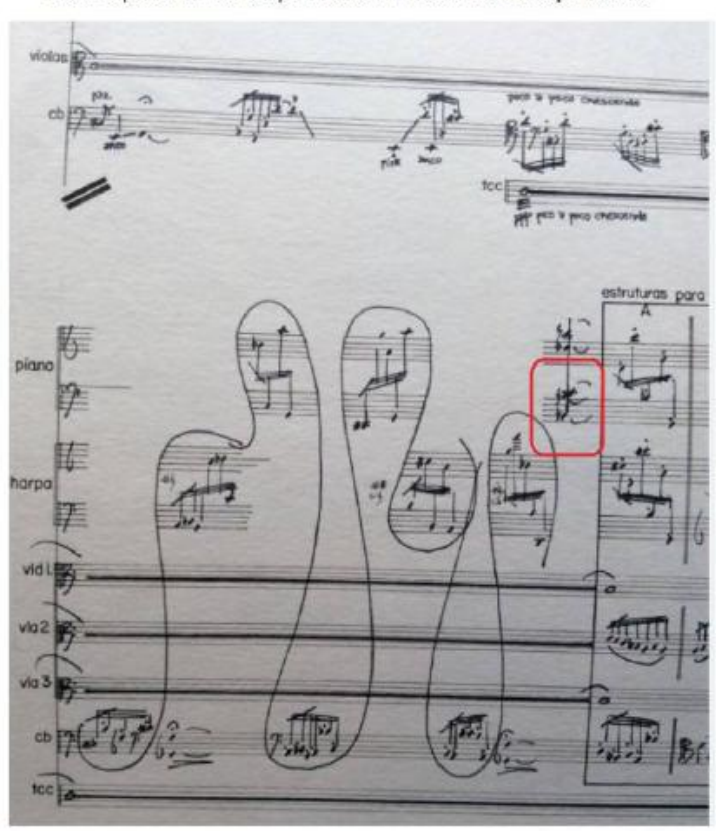

Estética do Frio II

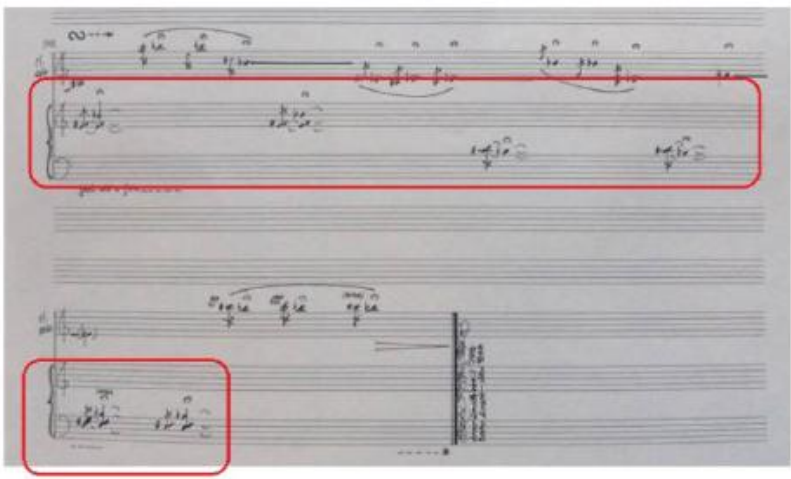

Engenharia de papel

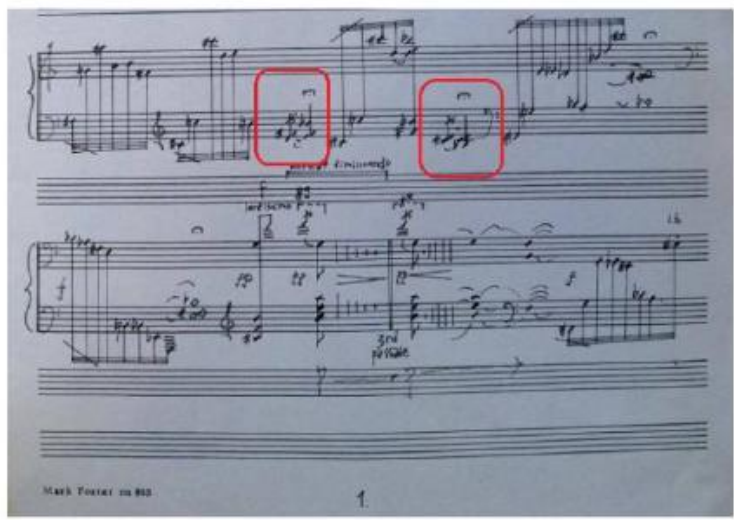

\subsubsection{Acorde-âncora}

Acorde-âncora é o nome dado pelo compositor a um bloco harmônico formado pelas notas Lá, Si bemol, Ré e Mi (agrupadas no mesmo registro), o qual aparece em momentos distintos de Estética do Frio III. Este acorde emerge em trechos específicos da obra, imprimindo-lhe uma sonoridade singular. São ao todo seis incursóes: cinco no piano c. 24-28, c. 39-42, c. 43-44, c. 52 e c. 53 e 54 e uma na viola e no violoncelo c. 122-123. 
FIGURA 12 - acorde-âncora. A imagem apresenta algumas das incursões do acorde-âncora na obra. Da esquerda para direita estão c. 24-25, c. 52, c. 54 e c. 122-123.
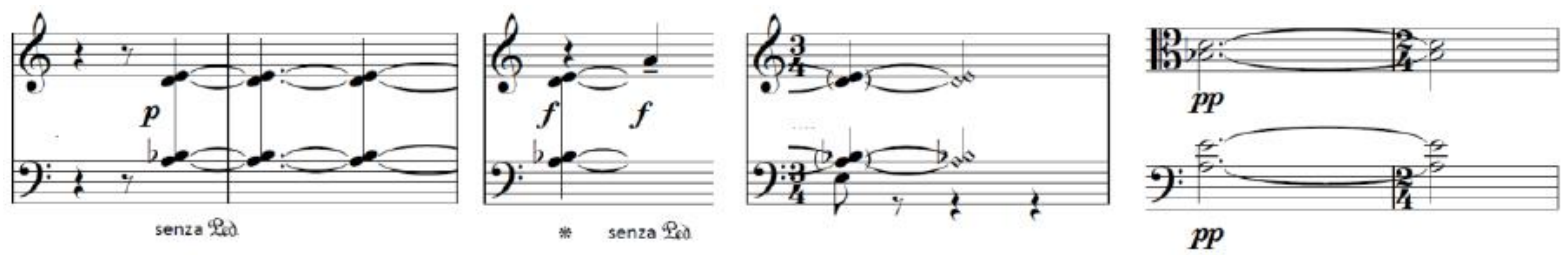

O que chamou a atenção do compositor neste acorde - e o motivo de tê-lo agregado ao processo composicional - foi seu poder de ressonância.

Curiosamente, as mesmas notas do acorde-âncora aparecem também no Estudo Paulistano para piano (1998). Entretanto, diferente de Estética do Frio III, na qual este acorde é sempre um bloco vertical estático, no Estudo Paulistano, além da ação vertical (com a diferença de que a nota Mi passa para o baixo), as notas do acorde são arpejadas e, em seu decorrer, sofrem pequenas alterações intervalares. Embora as diferenças, o sentido expressivo é o mesmo e a sonoridade extremamente semelhante.

FIGURA 13 - Acorde-âncora no Estudo Paulistano.

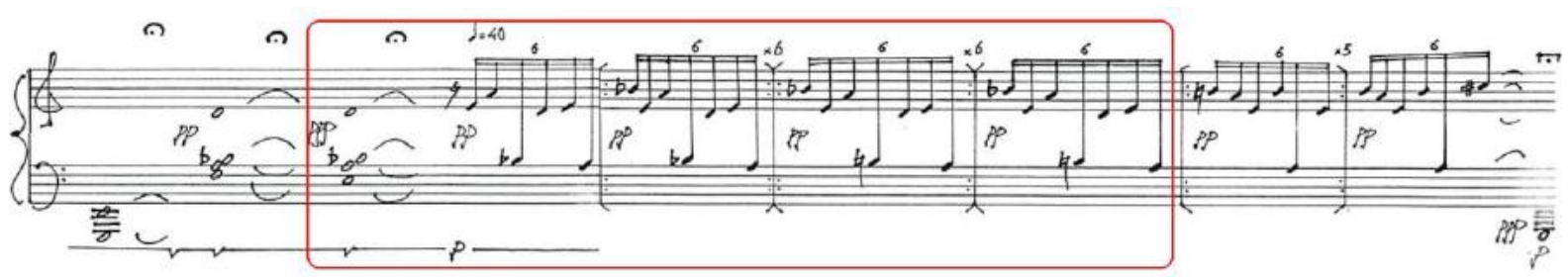

Conquanto o material seja praticamente o mesmo, a utilização deste acorde em Estética do Frio III não acontece como uma atitude deliberada de revisitar Estudo Paulistano. É possível que sua reminiscência tenha se entrelaçado com o processo criativo. Em relato pessoal, o compositor (2016) explica que não lembra como o acorde âncora foi agregado ao processo composicional de Estética do Frio III e que, certamente, não deriva de uma proposta que vise evocar outras composições, reconhece, no entanto, que a natureza sonora e estrutural entre ambos os eventos é a mesma. Para além das questôes de processuais da peça, este material pode ser visto como um texto no nível estésico, pois possui carga referencial suficiente para tornar possíveis associações com outras obras do compositor. 


\subsubsection{Doze Acordes}

Os doze acordes formam uma sequência criada para fornecer materiais harmônicos e melódicos para Estética do Frio III. Eles podem ser interpretados como o principal elemento generativo da peça, pois através deles o compositor cria a maioria dos eventos. Esta abordagem técnica age como um método composicional que emerge do corpo de regras do código estrutural da cadeia harmônica.

Segundo o compositor (2015), os doze acordes foram criados visando obter uma sequência harmônica sonoramente eficiente, em que os acordes "soassem bem em si, e em relação aos outros". A diretriz que conduziu a construção dos doze acordes assentou-se no afastamento em relação a voice-leading, o qual se refere simplesmente à ideia de evitar, no processo de construção dos acordes, terças, quintas e sextas adjacentes. Os acordes resultantes deste processo são formados predominantemente por intervalos de quartas e segundas. Esse critério não impediu a ocorrência de desvios (através da utilização de terças/décimas, quintas e sextas), pois o julgamento das escolhas foi orientado "pela carga expressiva dos materiais e de seu possível potencial em tornar-se música” (CHAVES, 2015).

FIGURA 14 - Manuscrito dos doze acordes ${ }^{23}$.

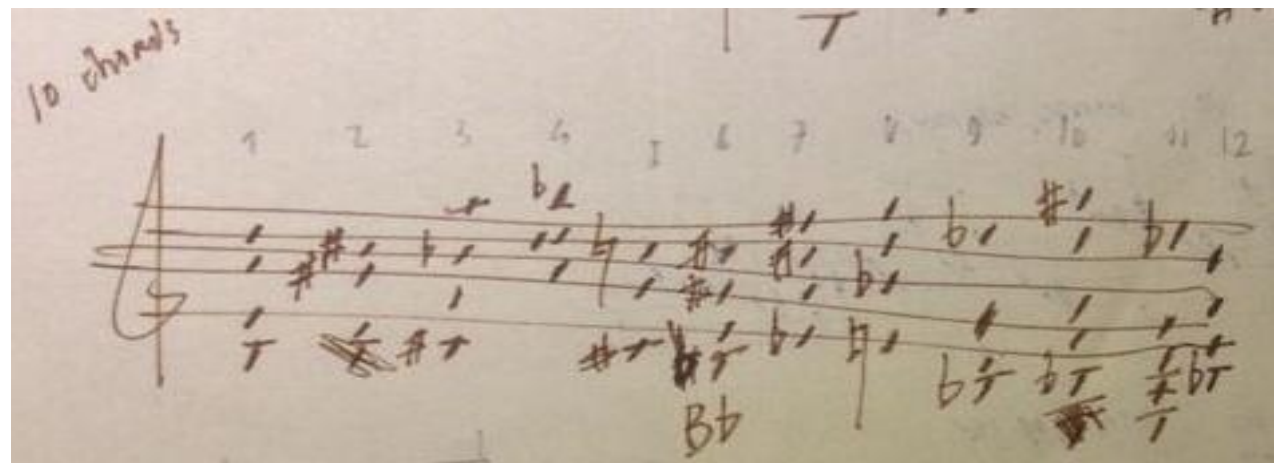

\footnotetext{
${ }^{23}$ A cada dois acordes há um movimento de aproximação por meios cromáticos (por exemplo, entre o $1^{\circ}$ e $2^{\circ}, 3^{\circ}$ e $4^{\circ}, 5^{\circ}$ e $6^{\circ}$ ), que geram uma espécie de tensão/relaxamento da cadeia harmônica. A conexão destes acordes surge, predominantemente, por movimentos paralelos ascendentes e descendentes, saltos, subtração/adição de notas (há acordes de 3 , 4 e 5 notas). O movimento entre o $2^{\circ}$ e o $3^{\circ}\left(4^{\circ}\right.$ e $5^{\circ}, 6$ e $7^{\circ}$ etc.) ocorre por saltos nas vozes extremas, pelo movimento cromático entre as vozes intermediárias das notas adjuntas, por repetição de nota. Esses elementos estabelecem um coeficiente orgânico na conexão de um acorde com o outro, gerando equilíbrio harmônico na sequência.
} 
A maioria dos acordes foi construída em posição cerrada, ocupando uma extensão de, no máximo, duas oitavas. Entretanto, quando os acordes são utilizados no processo composicional, a disposição das notas ou registro adquire pouca importância.

O trecho Teoria dos acordes (Fig. 15), situado na seção E do segundo movimento, por exemplo, reflete uma das formas pelas quais o material dos doze acordes é utilizado. O que o compositor refere como teoria dos acordes consiste na exposição e na confluência de dois dos três materiais genéticos da peça: os doze acordes e o ritmo Vivat, Vivat Regina! ${ }^{24}$. O material Vivat, vivat Regina! fornece o molde rítmico e o extraído dos doze acordes, o conteúdo harmônico, os quais, juntos, compóem a sonoridade e o caráter expressivo da parte E.

Este trecho é um dos momentos em que os doze acordes são empregados para a construção de blocos harmônicos. Outro tipo de procedimento criativo, recorrente em Estética do Frio III, envolvendo os doze acordes está relacionado à criação de frases e melodias.

FIGURA 15 - teoria dos acordes. A imagem mostra os dois momentos em que a teoria dos acordes está presente na obra. O pentagrama superior corresponde a c. 97-102, o inferior, a c. 108-115. O trecho sublinhado em vermelho c. 110-113 representa a forma original do material genético Vivat, vivat regina!, adaptado e expandido nos demais trechos da mesma seção.

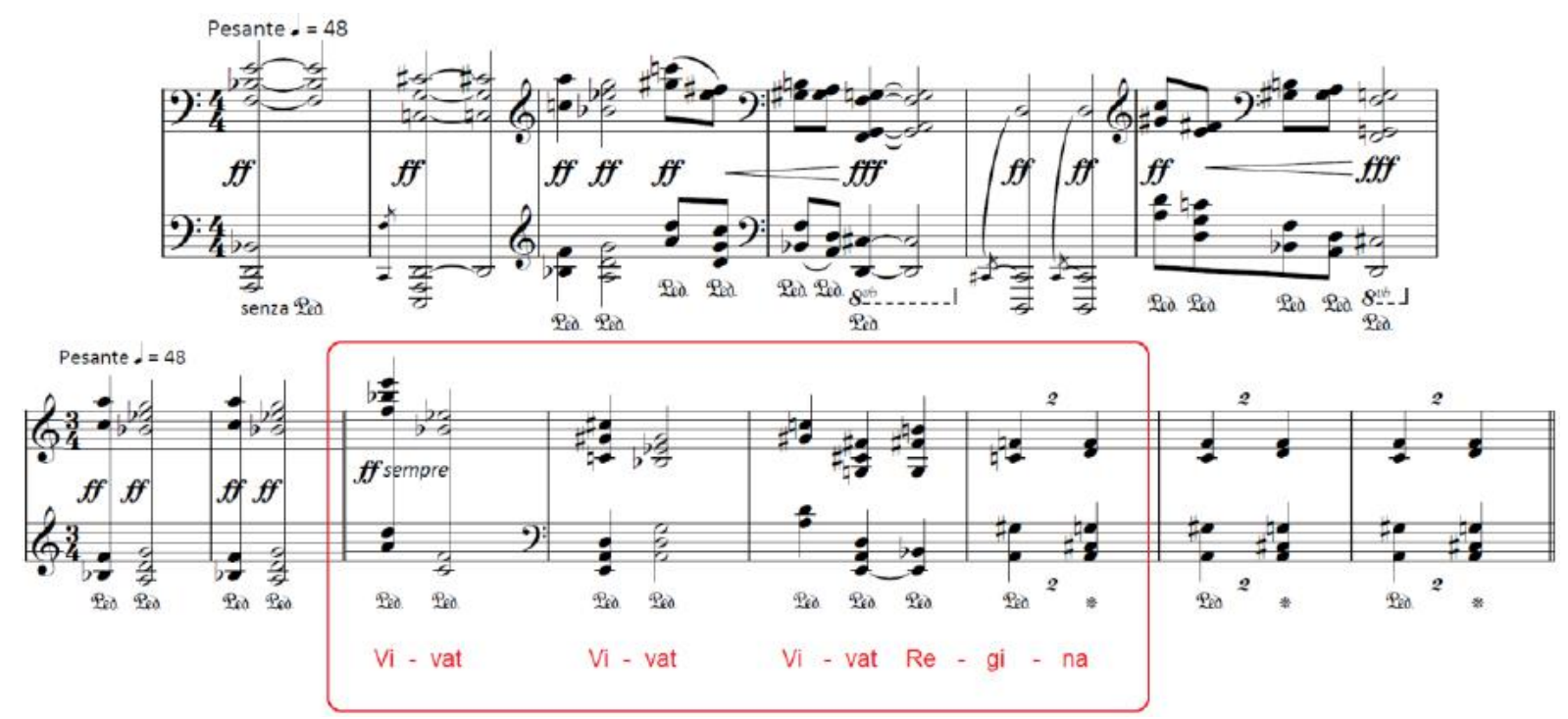

\footnotetext{
${ }^{24} \mathrm{O}$ ritmo Vivat, Vivat Regina! consiste em uma célula rítmica que integra os chamados materiais genéticos de Estética do Frio III. A valoração rítmica deste material rítmico corresponde à prosódia das palavras Vivat Regina, conforme mostrado na Fig. 15, representado pelo fragmento circulado. Assim como os demais materiais genéticos, o ritmo Vivat, Vivat Regina! foi originalmente concebido para uma peça para violáo, a qual não foi composta.
} 


\subsubsection{Processo composicional envolvendo os doze acordes}

O processo composicional envolvendo os doze acordes para a criação de melodias ocorre em três etapas. Na primeira, está a construção de linhas melódicas partindo dos doze acordes. Neste momento, o compositor examina o material e recolhe informações que poderão resultar em declaraçôes expressivas. Assim, o processo de escolha de alturas que resultou em doze acordes é posto à prova, "pois terão que demonstrar sua eficiência nesta operação de construção de linhas horizontais que deverão ser igualmente eficientes” (CHAVES, 2015).

$\mathrm{Na}$ segunda etapa, as linhas resultantes da anterior são submetidas a uma ordenação rítmica. As tomadas de decisão ganham maior liberdade para dar sentido musical às linhas melódicas resultantes. O compositor permite-se jogar com as possibilidades do ritmo, atribuindo aos materiais objetivos expressivos. Aqui é o ponto no qual ocorrem os desvios estruturais mais intensos. A identidade intervalar está resolvida estruturalmente, porém a ausência de um contexto rítmico constitui um campo aberto para o compositor explorar contrastes entre os eventos.

$\mathrm{Na}$ última etapa, são tomadas decisões sobre a textura, resultando na música em si.

\subsubsection{Doze acordes no trecho Deserto}

O processo de extração de melodias é ilustrado pelo trecho Deserto c. 128-134.

FIGURA 16 - Deserto c. 128-134, parte G.

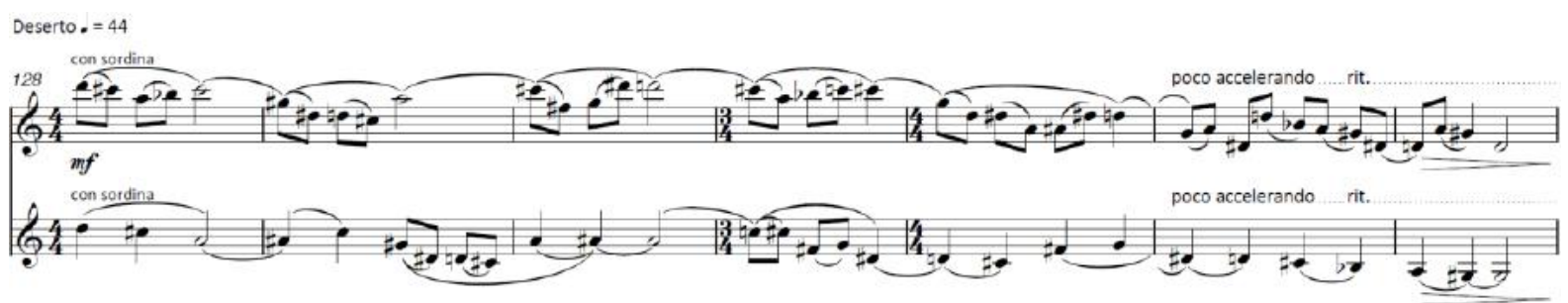

Através de alguns manuscritos, mapearam-se, em parte, as tomadas de decisão. O processo de criação de melodias deste trecho pôde ser recriado através do manuscrito (Fig. 17), que revela quais melodias e fragmentos resultaram na melodia definitiva. 
CORRÊA, João Francisco de Souza. 0 processo composicional intertextual de Estética do Frio III de Celso Loureiro Chaves. Revista

FIGURA 17 - Manuscrito do processo de elaboração de melodias a partir dos doze acordes do trecho Deserto ${ }^{25}$.

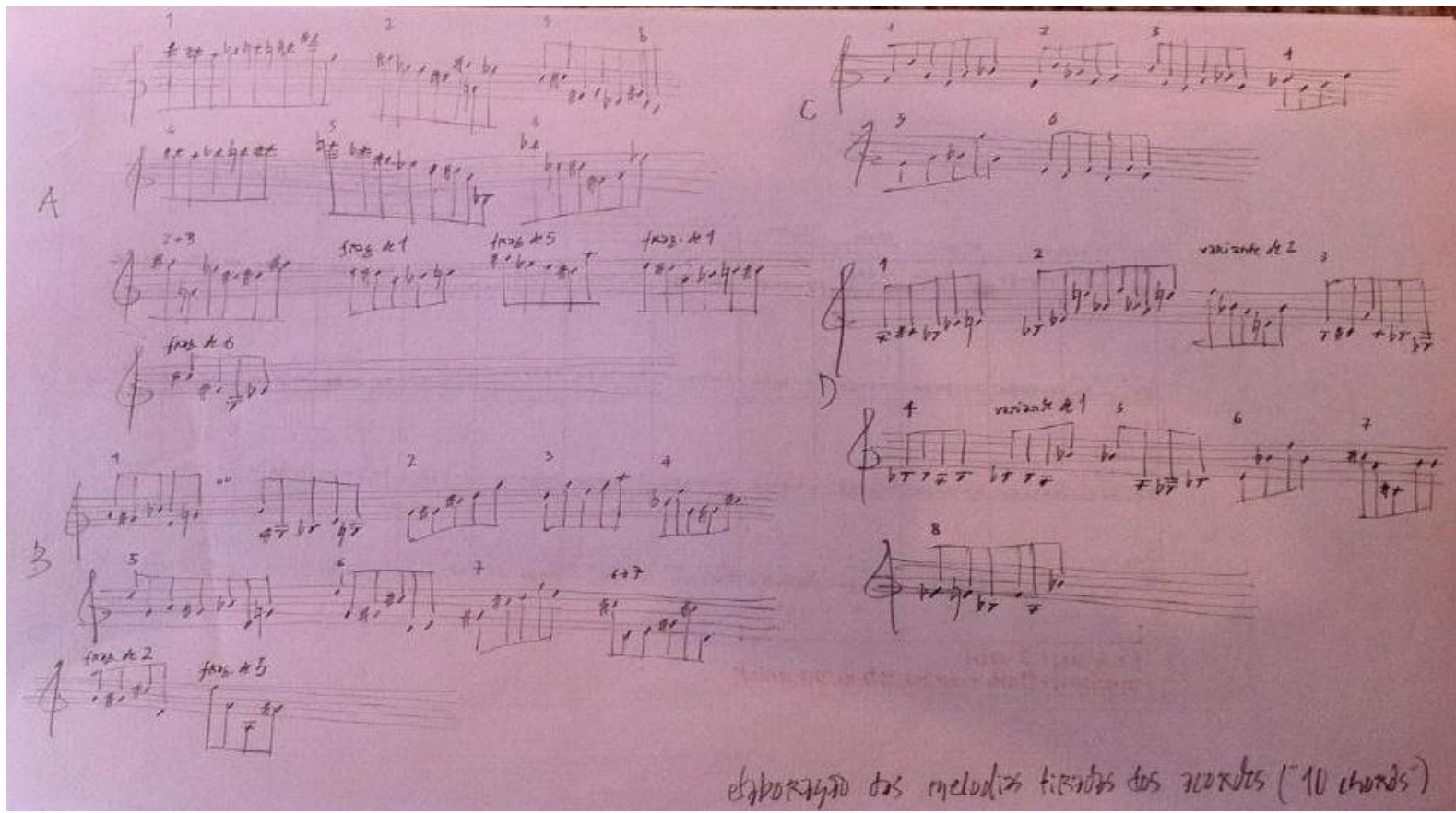

Para a criação dos quatro primeiros compassos da linha melódica do primeiro violino ${ }^{26}$, foram utilizadas apenas algumas das melodias do conteúdo A (Fig. 17, no alto, à direita).

A Fig. 18 representa o processo que inicia com a extração de linhas melódicas dos doze acordes e culmina na linha melódica da partitura. Para cada um dos quatro compassos aqui abordados, há quatro pentagramas que, como se fossem etapas do processo, representam ordenadamente: acordes, melodias, fragmentos destas melodias, materiais resultantes.

\footnotetext{
${ }^{25}$ Nesta página de manuscritos, o compositor cria uma série de melodias e fragmentos, testando as possibilidades do material. Apenas uma pequena parte foi suficiente para organizar a melodia definitiva do trecho Deserto, dividido em quatro segmentos de conteúdo (A, B, C e D). Cada um contém uma série de melodias, que variam entre seis e oito notas, e fragmentos, que são excertos menores derivados de melodias ou de combinaçốes entre elas.

${ }^{26} \mathrm{O}$ segundo violino realiza, uma oitava abaixo, um contracanto quase imitativo.
} 
FIGURA 18 - Representação do processo de criação de melodias dos c. 128-134. Através das notas extraídas dos doze acordes, estas melodias são submetidas a um processo redutivo, em que segmentos maiores são reduzidos a segmentos menores - de blocos de acordes em sequência a linhas horizontais, de linhas horizontais a fragmentos melódicos, de fragmentos melódicos ao material final (com ritmo, registro e instrumentação).
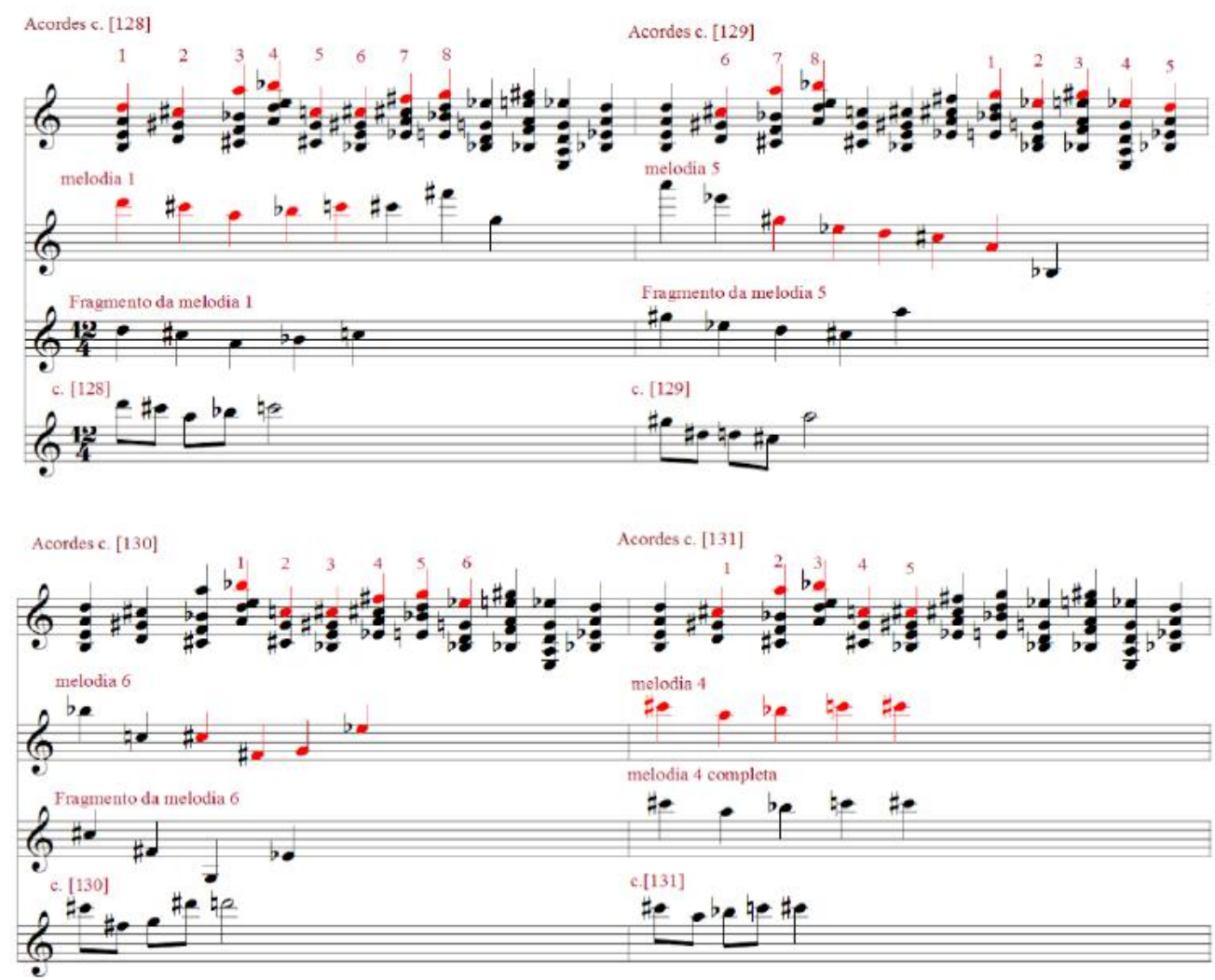

No primeiro pentagrama, estão sublinhadas, em vermelho, as melodias extraídas dos doze acordes. Neste trecho, todas as melodias são extraídas das vozes extremas dos acordes. Havendo uma nota escolhida como ponto de partida, as seguintes são sempre suas vizinhas situadas em seu lado direito. Apenas na construção da melodia em c. 129, houve um salto na escolha das notas.

No segundo pentagrama, são mostradas as melodias integrais, estando em vermelho os fragmentos aproveitados. Tais melodias estão numeradas, no conteúdo A, de 1 a 6 (Fig. 17). Neste ponto, ainda que de modo indefinido, já acontecem adaptações de registro, entretanto ainda há notas sobressalentes.

No terceiro pentagrama, estão os fragmentos das melodias. Aqui, algumas notas das extremidades das melodias são descartadas. Estes fragmentos contêm o conteúdo melódico utilizado na melodia final. No c. 131, a melodia extraída dos acordes não foi reduzida a um fragmento, mas utilizada de forma integral. 
O quarto pentagrama mostra a melodia resultante, com ritmo e registro definidos. No c. 130 é somada a nota Ré para completar o padrão de cinco notas em cada compasso deste trecho.

\section{Conclusão}

Pela investigação sobre os elementos que o compositor insere na criação de sua obra, aqui entendidos como textos, visou-se compreender o modo como o compositor realizou o processo de apropriação intertextual; quais as abordagens composicionais envolvidas; como elas operam sob o ponto de vista prático e funcional; quais os paralelos entre os textos, em seu contexto original, e sua reinserção em Estética do Frio III; como mudanças e transformações aplicadas aos textos informam sua percepção como elementos referenciais e alusivos.

Com o intento de contemplar tais questôes, foram colocados em discussão: aspectos históricos e composicionais das obras citadas; apontamentos teóricos para explicar as diferentes demandas processuais, empreendidas nos textos; escritos, relatos e manuscritos do próprio compositor, para embasar as reflexões sobre os procedimentos composicionais intertextuais.

Através da investigação destes aspectos, mapearam-se os diferentes textos que constituem Estética do Frio III, bem como a forma como Chaves os utiliza.

Com relação ao modo como o compositor emprega os textos em sua obra, destacam-se:

a) utilização de grande quantidade de textos citacionais - amalgamando citações de diferentes espécies, Estética do Frio III faz referência a obras de Bernstein, Bartók, Albuquerque e do próprio compositor. Os textos citacionais aparecem apenas uma vez, em momentos pontuais. Os textos e materiais do compositor costumam retornar no decurso da obra;

b) reexposição e ressignificação do conteúdo musical apropriado - a comparação com o contexto original de cada citação esclarece que a maioria das abordagens processuais reexpóem o conteúdo musical, conservando as sonoridades aludidas. Há, em menor quantidade, casos de adaptaçóes e mudanças significativas sobre o conteúdo. Neles, os textos tem sua carga referencial diluída, a fim de cumprirem determinadas funções, dentro do contexto estrutural da obra;

c) alcance de unidade - a ideia de um processo intertextual, envolvendo ampla gama de referências 
externas, coloca em risco a unidade. Tal problema é neutralizado não somente pelo modo como tais referências são organizadas, mas também por adotar doze acordes como epicentro do processo de criação de melodias e harmonias. Os doze acordes garantem a solidez orgânica e estrutural que permite ao compositor incorporar vários e diferentes elementos, sem comprometer a unidade. A recorrência de determinados materiais e o uso de conectivos entre diferentes partes também contribuem neste aspecto.

d) os textos e suas funçôes - os textos empregados em Estética do Frio III podem ser organizados em três tipos principais, de acordo com sua função: 1) como elemento de transição; 2) como elemento de quebra da linearidade; 3) como elemento transfigurado e não referencial. No primeiro, os textos são empregados, como elemento de transição, entre partes ou entre eventos distintos. No segundo, eles são colocados em meio a um evento ou contexto sonoro, provocando ruptura na sonoridade estabelecida. Com estes textos, a sonoridade da obra atualiza-se subitamente, como se fosse um parêntese em meio a um discurso. No terceiro, o conteúdo dos textos ou seu contexto original é transfigurado de tal forma que a referencialidade fica totalmente eliminada.

O processo criativo empreendido na obra Estética do Frio III - Homenagem a Leonard Bernstein revela ser possível obter um resultado eficiente, por meio de uma abordagem composicional intertextual plural e carregada de referências. A estratégia para obter organicidade, mesmo com o uso abundante de elementos alusivos, está relacionada com um planejamento estrutural bem definido, derivado da adoção de um conjunto de acordes, visando à criação de grande parte dos eventos da obra. Neste cenário, os materiais externos utilizados pelo compositor encontram uma sólida estrutura de conexão, levando a composição a operar e soar de forma coerente. 


\section{REFERÊNCIAS}

BERNSTEIN, Leonard. Nota do prefácio da partitura de Age of Anxiety. Edição Boosey \& Hawkes, 1993.

BURKHOLDER, J. Peter. Verbete Quotation. in Grove Music online. Oxford Music Online. 2001. Disponível em: http://www.oxfordmusiconline.com/subscriber/article/grove/music/52854. Acesso em: 8 de fev. 2017.

CHAVES, Celso L. Memória, Citação e Referência: os Fluxos do Tempo no "Estudo Paulistano" de Celso Loureiro Chaves. Porto Alegre: Anais do XV Congresso da ANPPOM, 2003.

. Estética do Frio III: Homenagem a Leonard Bernstein. Quarteto Osesp e Jean-Efflam Bavouzet. In: Encomendas OSESP 2014. São Paulo: Selo Digital OSESP 8, 2014. Disponível em: $<$ http://www.osesp.art.br/paginadinamica.aspx?pagina=cdencomendasosesp2014 $>$. Acesso em: 4 de jun. 2015.

Estética do Frio III. Porto Alegre: Edição do Autor, 2014. Partitura, 27 páginas. Dois violinos, viola, violoncelo e piano. publicado.

. Roteiro da paisagem. Porto Alegre, 09 mar. 2015, 08 jul. 2015. 4 páginas. Material não

. Encarte do CD Encomendas OSESP. 2014. Ronaldo Miranda, Alexandre Lunsquy, Celso Loureiro Chaves. 23 p.

Conversa pessoal. Porto Alegre, 2016. Explicações sobre o processo composicional de Estética do Frio III durante as orientações do Doutorado. Notas de aula. Material não publicado. Entrevista.

GENTRY, Philip. Leonard Bernstein's The Age of Anxiety: A Great American Symphony during McCarthyism. American Music, Vol. 29, No. 3. University of Illinois Press. pp. 308-33. Outono/2011.

KLEIN, Michael. Intertextuality in Western Art Music. Bloomington: IndianaUniversity Press, 2005.

ROSS, Alex. O resto é ruido, escutando o século XX. Tradução Claudio Carina, Ivan Eisz Kuck. São Paulo: Companhia das Letras, 2009.

SCHUTZ, Alfred. Fragments on the phenomenology of music. In: SMITH, F.J. (Ed.). In Search of Musical Method. London: Gordon \& Breach, 1976. p. 5-71.

STRAUS, Joseph N. Remaking the Past: Musical Modernism and the Influence of the Tonal Tradition. Cambridge, Mass.: Harvard University Press, 1990. 
CORRÊA, João Francisco de Souza. O processo composicional intertextual de Estética do Frio III de Celso Loureiro Chaves. Revista Vórtex, Curitiba, v.8, n.2, p. 1-32, 2020.

\section{SOBRE O AUTOR}

João Francisco de Souza Corrêa é doutor em composição musical pela Universidade Federal do Rio Grande do Sul, UFRGS (2019). Possui bacharelado em violão pela Universidade Federal de Pelotas, UFPEL (2008) e mestrado em Teoria e Criação pela Universidade Federal do Paraná, UFPR (2013). Seus trabalhos e pesquisas abordam especialmente os seguintes temas: intertextualidade, composição, violão, arranjo, análise musical e educação musical. Atualmente realiza o curso de pós-doutorado em música na Universidade Federal do Rio Grande do Sul. ORCID: https://orcid.org/0000-0002-1362-6649. E-mail: joaofscorrea@hotmail.com 